\title{
EXPENSE ACCOUNTS FOR EXECUTIVES *
}

\section{$V$. HEHRY ROTHSCHILD $†$ and RUDOLF SOBERNHEIM††}

EXPENSE account spending, conservatively estimated at five billion dollars a year, has been said to result in an annual tax loss to the federal government of one to two billion dollars. ${ }^{1}$ The expense account will often accord the executive a standard of living otherwise beyond his means, ${ }^{2}$ particularly in the advertising, television, public relations and other sales and promotional fields. ${ }^{3}$ The spending encouraged by the expense account makes it an important

\footnotetext{
*This article is based upon sections of a forthcoming third edition of WAsHINGTON \& Rothischin, Compensating the Corporate Executive (2d ed. 1951), scheduled for publication in 1959 by The Ronald Press Company.

† Member of the New York and Federal Bars; former Vice-Chairman and Chief Counsel, Salary Stabilization Board; lecturer on executive compensation and related subjects; author or coauthor of Compensating the CoRporate Executive, Deferred Comipensation for Executives, Financing Stock Purchases by Executives, and other books and articles appearing in legal and nonlegal publications.

HMember of the New York and District of Columbia Bars; Assistant Counsel, Bureau of Ships, Department of the Navy; former Assistant Chief Counsel, Office of Salary Stabilization; chief research assistant and editor, Compensating tre Corporate Executive; author or coauthor of Salary Stabilization Under Defense Mobilization, Collective Bargaining on Stock Purchase Plans: What Price Employee Stock OwnerSHIP?, and other articles.

1. Expense Accounts: $A \$ 5$ Billion Tax Deduction, and Growring, U.S. News and World Report, Aug. 16, 1957, p. 83; see Barcella, New Accounting of Expense Accounts, N.Y. Times Magazine, April 20, 1958, p. 48, col. 1 ("A Revenue Service spokesman says its a very conservative guess that about $\$ 5$ billion, perhaps even $\$ 10$ billion, is spent on expense accounts annually") ; Edwards, Life on the Cuff, Today's Living, March 17, 1957, p. 4 (quoting a Harvard estimate of $\$ 6.5$ billion spent by about one million "outside salesmen") ; Havemann, The Expense Account Aristocracy, Life, March 9, 1953, p. 140 ("This is the Age of the Expense Account, an institution which taxation has inflated into almost appalling importance").

2. See Morgan, Expense Account (1958), a novel about a corporate executive who fumes "about his Monday-Friday membership in the aristocracy of the expense account and the disparate reality of the weekends which he spent with the payroll peasants and their budgets and bills, bargains and bank loans." Id. at 18. See Havemann, supra note 1.

3. Expense Accounts: $A \$ 5$ Billion Tax Deduction, and Grouring, supra note 1 , at 86 (based on checking Diners' Club bills) ; Gehman, Expense Accounts, Cosmopolitan, March 7, 1957, p. 44; Osmond, The Corporate Executive and the Business Expense Deduction, 33 TAxES 68 (1955) (suggesting that expense reimbursement practices of corporations represent an attempt to give their executives the benefits of expense deductions more freely available to salesmen, independent entrepreneurs and professional men). A link has been recognized between large expense accounts-especially for entertainment-and general prosperity, which induces less careful scrutiny of spending. But repeal of the excess profits tax, often cited as a stimulus to expense account spending, does not appear to have led to its decline. The Age of the Expense Account, 45 MGar. REv. 283 (1956).
} 
source of income for a number of industries and services-among them restaurants, theaters, theater brokers and resort hotels throughout the country. Moreover, it has inspired if not engendered its own supporting industry-the credit-card club. ${ }^{5}$ Inevitably, the expense account presents problems of tax enforcement made acute by the self-assessment system for reporting income. ${ }^{0}$ From time to time, the Treasury Department has adopted measures designed to cope with these problems, the most recent of which is a proposed reporting requirement for 1958 and subsequent years intended to disclose high expenses. ${ }^{7}$

This Article will discuss expense account spending, both as a corporate and tax matter, and will then suggest a somewhat different approach to controlling the expense account.

\section{The Expense Account in Corporate Practice}

Except for personnel directly connected with sales, the large, publicly-held company employs the expense account primarily for its top executives. ${ }^{8}$ Its

4. "In cities like New York, Washington and Chicago it is safe to say that at any given moment well over half of all the people in the best hotels, the best nightclubs and the best restaurants are charging the bill as an expense account item to their companies ...." Havemann, supra note 1, at 140; see Gehman, supra note 3, at 44-45. It has been estimated that 30 to $40 \%$ of all theater tickets are bought on expense accounts and that $80 \%$ of the patrons of new, high-priced restaurants are there "on the company." Expense Accounts: $A \$ 5$ Billion Tax Deduction, and Growing, supra note 1, at 86; see Mannes, Broadway Speculations: The Expense Account in Theater, Reporter, Apri1 7, 1955, p. 39 ("Theater people estimate that thirty to forty per cent of the New York theater audience is an expense-account audience, and that this is the percentage between life and death [for the theater]") ; Thruelsen, Fanciest Vittles This Side of Paris, Saturday Evening Post, April 28,1956, p. 35 (describing a $\$ 550$ expense account dinner at Le Pavillon, a New York restaurant); compare HAwLEY, CASH McCALL 7-8 (1955) (characterizing the fictitious Fontainebleat Room in the following terms: "Although the Fontainebleau Room is advertised as The Mecca of the Gourmet, its successful existence is less an index to the culinary prowess of its famous chef de cuisine ... than to the phenomenon of the unlimited expense account, and the tolerance of the Bureau of Internal Revenue in the auditing of accounts chargeable as ENTERTAINMENT").

5. 'One of the stocks I have been recommending is the Diners' Club. Living on expense account is one of the ways smart people have mitigated taxes." The Investor, Oct. 1957, p. 11 (quoting Walter Gutman, investment advisor). For the early history of the Diners' Club, see N.Y. Herald Tribune, Nov. 1, 1953, $\$ 2$, p. 7, col. 1 (referring to a $\$ 25,000$ bill of one executive). Other credit-card clubs include Esquire, Universal Travelcard, Gourmet Guest and American Express.

6. See Smith, Watch Your Expense Acconnts, Harv. Bus. Rev., Jan.-Feb. 1958, p. 120 (expressing concern lest dishonesty in the matter of expense accounts "lead to the eventual breakdown of our federal income tax system-the self-assessment system which, on the whole, has worked admirably for more than 40 years at a relatively modest cost of enforcement and collection").

7. Proposed U.S. Treas. Reg. 103, § 19.1, 23 FED. Reg. 1698 (1958), discussed notes 106-07 infra and accompanying text.

8. However, the expense account may be found at all management levels in advertising, motion picture, television and related industries. 
use to provide for payment or reimbursement of travel and entertainment expenses is also widespread among closely-held companies whose affairs are often interwoven with those of stockholder-executives owning and managing the companies without being accountable to third parties. ${ }^{9}$

Corporate practice recognizes as properly reimbursable those expenses coming within the two major categories of travel and entertainment. ${ }^{10}$ Travel on company business includes the cost of baggage handling, tips, hotel accommodations and food, and of telephone, telegraph, stenographic and other special services. Entertainment, both of the company's customers and, less frequently, of the executive's employees and business associates, includes the cost of restaurants, theaters, sporting events, gifts and, occasionally, the incidental expenses of home entertainment. ${ }^{11}$ Other expenses often reimbursed by the corporation are subscription costs for business journals and periodicals, dues of trade and professional associations, dues and charges of town and lunch clubs-occasionally of country clubs as well ${ }^{12}$-and operating costs of automobiles and airplanes. ${ }^{13}$ On the borderline between proper and improper expenses are laundry and valet charges, ${ }^{14}$ maintenance fees for yachts used primarily in entertaining company personnel and the costs of attending a convention, especially when it is incidental to a vacation trip or when the executive seeks to deduct the

9. Sanders, Effects of Taxation an Executives 144 (1951). Cf. id. at 143: "Whether a particular item of expense is a personal expense or an expense of the business is in many cases impossible of categorical answer because it is both."; $i d$. at 152: "[F] or all executives in positions of great importance, their business, social, and personal affairs are so much intermingled that it is not easy to draw the line between them ...."

10. The reference here is to general corporate practice, not the tax results of such practice, which are discussed in the following sections. Specific items mentioned are based on evidence of corporate practice found in authorities cited notes 1-9 stpra, and on various surveys. See Neuhoff, Executive Expense Accounts (Nat'l Ind. Conf. Bd. Studies in Bus. Policy No. 67, 1954); Executive Expense Practices, Am. Bus., Jan. 1957, p. 29; Executive Expenses Viewed Morosely, Bus. Week, April 10, 1954, p. 47; What Goes and What Wou't Go on Expense Accounts, Changing Times, Sept. 1954, p. 39; Reducing Youtr Expense Account Headaches, 43 MgMr. Rev. 305 (1954).

11. At-home entertainment was not found to be a common occurrence but was reimbursed by about half the companies surveyed by the Conference Board. NeuHoff, op. cit. supra note 10 , at 14.

12. Two out of three companies surveyed by the Conference Board paid club dues, but only in the case of top executives. Id. at 15.

13. In the Conference Board survey, mileage allowances were found to range from $6 \phi$ to $10 \%$ a mile, with the usual allowance being 7 or 84 . Id. at 10 . This survey was published in 1954. In 1955, the mileage allowance for government employees using their own cars on official business was increased from $7 \xi$ to $10 \phi$ a mile. 69 STAT. 394 (1955), 5 U.S.C. $\S 837$ (Supp. V, 1958). For the cost of airplane operation, see Management's 10,000 Plane Air Fleet, Fortune, Nov. 1953, p. 117. (Piper Tri-Pacer cost $6.4 \xi$ per mile; DC-3 about ten times that).

14. The Conference Board found that most of the companies in its survey paid laundry expenses during trips of over a week and valet expenses during trips of over three days. NeUHoff, op. cit. supra note 10, at 10. Compare Executive Expense Practices, supra note 10 (trips of 7-10 days and 4-7 days, respectively). 
traveling expenses of his wife. ${ }^{15}$ Frequently outside the sphere of reimbursable items are the costs of hunting, fishing and other sporting events.

Corporate practice generally refuses to recognize entertainment, telephone and other charges considered personal, barber services, shoeshines, excessive taxi fares, cocktails, movies, tobacco and magazines for self-entertainment away from home, valet and laundry charges for short trips and, generally, overspending for meals, tips and similar items.

Some corporations have recognized the desirability of an expense clause in the employment contract when substantial expenses are contemplated. The clause serves not only to avoid the possibility of future controversy and to protect the directors from stockholder criticism, but also to simplify the tax position of both corporation and executive. A typical clause reads :

It is contemplated that in performing services hereunder the Executive will be required to incur entertainment expense in the interests and on behalf of the Corporation and in furtherance of its business. To defray such expense the Corporation agrees to make available to the Executive sums not to exceed a total of $\$$.... per annum. Subject to such limitation in amount, the Corporation at the end of each month during the period of this agreement will, upon submission of appropriate bills or vouchers, pay all such expense incurred by the Executive during such month, such payment to be made either directly to the payee named in such bills or vouchers, or, to the extent paid by the Executive, by reimbursement of the Executive. The Executive agrees to maintain adequate records, in such detail as the Corporation may reasonably request, of all expenses to be reimbursed by the Corporation hereunder and to make such records available for inspection as and when requested by the Corporation. The provisions of this paragraph are not intended to apply to traveling expense or to business expense (other than entertainment) incurred by the Executive with the specific approval of the Corporation and such expense, as and when incurred, shall be separately paid, or reimbursed to the Executive, by the Corporation, upon submission of appropriate bills or vouchers and upon his maintenance of adequate records, but otherwise without reference to the provisions of this paragraph.

By way of variation, the expense clause may provide for reimbursement of all actual expenses or those of a designated nature, ${ }^{16}$ or for payment of expenses

15. The Conference Board found that few companies pay the expenses of the wife of a top executive on an extended trip even when the wife's presence "is considered a business asset." Neunorf, op. cit. supra note 10, at 12 . For an example of a contractual provision for such payment, see Washington \& Rothschild, Compensating the CoRporate ExECUTIVE app. K (2d ed. 1951) (hereinafter cited as Washington \& RoTHSCHILD) (Universal contracts with William J. Scully). For tax treatment, see notes 17, 73-74 infra and accompanying text.

16. See Casey \& Rothschild, Pay Contracts With Key Men exh. 165 (1953) (hereinafter cited as CASEY \& RotrschiLD) (Pepsi-Cola contract with Alfred N. Steel: "All travel and other expenses incident to the rendering of services by the Executive hereunder") ; id. exh. 166 (Universal contract with N. J. Blumberg: "All reasonable entertainment and other expenses incurred or expended by him in the performance of his duties hereunder for Universal"); id. exh. 169 (Loew's, Inc. contract with William F. 
up to a maximum figure, ${ }^{17}$ with or without a requirement for vouchers or other detail.18 Or the clause may stipulate payment of a fixed weekly, monthly or annual sum. ${ }^{10}$ Separate provision may be made for specific facilities which the executive is to keep at the disposal of the corporation, and for the business use of which he is to be paid. ${ }^{20}$ And though the type of clause set forth above contemplates separate payment of business expenses outside the category of entertainment, such a clause may of course limit payment or reimbursement to non-

Rodgers: "All reasonable and necessary expenses incurred, including living and traveling expenses of such official travel"). In Executive Expense Practices, supra note 10, the survey found that $55 \%$ of the companies surveyed reimbursed executives for their expenditures, $37 \%$ combined reimbursement with direct payment of expenses incurred by executives and only $7 \%$ had flat expense allowances; of the companies with flat expense allowances, over one half had fewer than 1,000 employees.

17. See, e.g., CASEY \& Rotrschild exh. 167 (Loew's, Inc. contract with Louis B. Mayer: expenditures for meetings and entertainment, whether at home or elsewhere, and for appropriate gifts up to $\$ 20,000$ ) ; WASHINGTON \& RoTHSCHILD app. E (Burlington Mills contract with Herbert M. Kaiser, providing up to $\$ 20,000$ annually for cost of entertainment and incidental expenses). When the contract contemplates long periods of travel away from home, the executive is sometimes reimbursed for his wife's travel expenses. $I d$. app. K, $\mathbb{2} 2$ (Universal contract with William J. Scully; travel in excess of two weeks) ; see CASEY \& RothsChILD exh. 166. For discussion of deductibility by the executive of his wife's travel expenses, see notes 73-74 infra and accompanying text.

18. CASEX \& RorHSCHILD exh. 165 ("The Company will reimburse the Executive on presentation of expense accounts for any such entertainment expenses, which are adaptable to the usual accounting procedures of the Company"); id. exh. 166 ("expenses shall be paid promptly as vouchers therefor are presented by Blumberg"); id. exh. 167 (Loew's will promptly reimburse Mr. Mayer for such expenditures upon the submission from time to time of statements therefor"); see WASBINGTON \& RotHSCHILD app. B (bills required for traveling expense only).

19. See, e.g., Casey \& Rothscrild exh. 168 (Panhandle Producing \& Refining Co. contract with Roger Gilbert; $\$ 250$ per month for entertainment expenses); $i d$. exh. 169 (Loew's, Inc. contract with William F. Rodgers: "\$200 per week (in addition to the traveling expenses, if any, hereinbefore provided), for unusual expenses incurred in behalf of the Corporation for which it is diffcult or impossible for Rodgers to account in detail"); see also Paramount Pictures, Inc. contract with Reuben B. Bolstad, Dec. 31, 1945, SEC Rep. Form SK (March 1946) ( $\$ 75$ per week from a subsidiary of the employing corporation).

20. Washington \& Rothschild app. I, $\llbracket 6$ (Burlington Mills contract with J. Spencer Love: "It is understood and agreed that the services required of Love ... by this contract include the duty of entertainment which Love ... shall deem to be in the interest of the Corporation's business .... The Corporation also acknowledges that Love . . . with the Corporation's approval, maintains a residence in Greensboro, North Carolina, a residence in Linville, North Carolina, a residence in Roaring Gap, North Carolina, a residence in Florida, and spends considerable time in New York City, and that he will continue to maintain such residences as he considers suitable; that when and while residing thereat, Love will be expected, as heretofore, to give all needful attention to the conduct of the Corporation's business, on the basis of which understanding the Corporation shall be committed to the payment of all Love's expenses incident to his travel to and from each of the aforesaid points. The Corporation will also maintain, at its own expense, such secretarial, telephone, transportation facilities, equipment, and other services at these points as may be necessary in the conduct of the Corporation's business"). 
entertainment expense. ${ }^{21}$ In most cases, payment or reimbursement for travel and similar nonentertainment expense is company practice without specific provisions in the employment contract.

As an alternative to paying or reimbursing expenses, the corporation may fix the executive's salary with a view to his assuming the payment of entertainment and similar costs. If the executive is to pay such bills himself, a clause in the employment contract to that effect, along the following lines, may be helpful from a corporate as well as a tax viewpoint:

The Company acknowledges that the successful operation and management of its business has required and will continue to require the Executive to expend, in the discharge of his duties as general manager and in the interests and on behalf of the Company and its business, substantial sums for traveling, board, meals and other usual business costs incident to relations with company personnel and with persons and representatives of companies with whom the Company has or might expect to conduct business. For such costs as are readily susceptible to the usual accounting, the Executive shall be reimbursed by the Company upon presentation of statements in the manner required by Company policy. For any other such costs as are not readily susceptible to the usual accounting, the Executive shall not be entitled to reimbursement, it being understood and agreed that his compensation has been determined with a view to enabling him to incur and pay costs of this nature on behalf of the Company out of such compensation.

For the controlling stockholder-executive of a closely-held company, this clause may not be desirable. By failing to identify the exact portion of overall payment representing salary, it leaves unfixed the amount of salary which the company can claim as a deduction for reasonable compensation. This uncertainty, coupled with the general absence of an arm's length relationship, renders an expense clause less useful to a controlling stockholder-executive than records properly substantiating the nature of payments or reimbursements made from time to time for specific expenses. ${ }^{22}$

Questions relating to the expense clause have arisen primarily in tax cases involving either the company's tax deduction or the executive's income tax or tax deductions. Stockholder litigation has been infrequent. ${ }^{23}$ It should be noted,

21. See CASEY \& RothsCHILD exh. 169 (reimbursement for expenses incurred in "official travel" and $\$ 200$ weekly allowance for "unusual expenses").

22. Cf. Rothschild, Compensation and Incentives for Executives, in ENCYCLOPEDIA of Tax Procedures 381, 390 (1956).

23. In Cohn v. Columbia Pictures Corp., N.Y. County Clerk's Index No. 9038/1950 (N.Y. Sup. Ct. 1.950), a stockholder's action against a corporation and its directors was based, among other things, on alleged payment by the corporation of : (1) the expense, including personnel, food and operation, of a yacht used one summer by the president of the corporation; (2) the cost of building and maintaining a projection theater at the home of the president; (3) the expense of New Year's Eve parties at the president's home; and (4) the price of clothes for the president's wife. In recommending approval of a settlement of the action, the Referee reported that: (1) "the corporation had a good business purpose in chartering the yacht for Mr. Cohn that summer. For the cost of charter and 
however, that the expense allowance, like any other corporate expense, can be criticized as either excessive in amount or wholly improper. ${ }^{24}$

\section{Income Tax Treatment of Expense Account Items}

\section{The Corporation's Deduction}

If a corporate executive entertains customers of the company in the interest of advancing its business relations, if he travels on company business away from the place where his office is located, or if he otherwise properly incurs expenses on behalf of his employer, payment of the executive's bills, either directly or by way of reimbursement, is normally deductible by the corporation as an ordinary and necessary business expense. ${ }^{25}$ The corporation may likewise take a deduction if, instead of paying or reimbursing specific expenses, it grants the execu-

maintenance they had him available throughout the summer at a time when he otherwise would have gone on vacation"; (2) the president's personal use of the projection theater to entertain some of his personal guests was "inconsequential when compared with the use to which it has been put for the benefit of" the corporation, and the $\$ 129,000$ cost of the theater, and the subsequent cost of its maintenance, were "a small enough consideration to pay for the extra services rendered by Mr. Cohn in this manner"; (3) three New Year's Eve parties, together costing about $\$ 9,000$, were "necessary and proper in order to foster a good relationship between the motion picture companies, the stars, and other persons in the industry"; and (4) the garments made for the president's wife by the company's wardrobe department were paid for on a cost plus $10 \%$ basis, and since they were made only "during the slack period ... idle personnel of the corporation were being used to good advantage." Referees Report Pursuant to Order Dated March 13, 1952, pp. 26-29 (July $8,1952)$. The settlement involved the president's payment to the corporation of $\$ 20,000$ toward a $\$ 40,000$ bill which had been paid by the corporation to attorneys employed for the president in connection with the negotiation of his employment contract. It also authorized the board of directors to increase the president's expense allowance to $\$ 600$ a week from the $\$ 300$ figure which had been paid since 1932. Cf. Heddendorff v. East Boston Corp. (D. Mass. 1958), reported in N.Y. Times, June 19, 1958, § 1, p. 22, col. 4 (stockholder action challenging, inter alia, $\$ 106,000$ of expenses, including $\$ 1,868$ for liquor, paid by the corporation for its president, Bernard Goldfine).

24. Charges of extravagant expense account spending have been involved in proxy contests. See, c.g., N.Y. Times, March 14, 1954, § 3, p. 1, col. 3, p. 10, cols. 3-4 (New Haven R.R.). See also id., April 9, 1954, p. 38, col. 1; Edwards, supra note 1, at 5 (both reporting stockholder charges against Lucian W. Sprague, chairman of the Minneapolis \& St. Louis Railroad, based on alleged corporate payment for "two big, powerful autos, a super first-class trip to Europe with Mrs. Sprague, and the cost of a private island retreat, not to mention occasional bills for groceries and flowers").

Corporations subject to regulation may also have expense items questioned by regulatory commissions. Thus, in fixing the operating expenses for fare-setting purposes, the District of Columbia Public Utilities Commission has disallowed travel and entertainment expenses of D.C. Transit, Inc., including the cost of a hotel apartment and long-distance telephone calls of the company's president. See Hearings Before the House Select Committee on Small Business on Complaints of Small-and Independent-Business Men Operating Sightsecing Businesses in the District of Columbia, 85th Cong., 2d Sess. 91-106 (1958).

25. Sanitary Farms Dairy, Inc., 25 T.C. 463 (1955) (deduction for safari expenses held legitimate); Slaymaker Lock Co., 18 T.C. 1001 (1952) (employee welfare expenses allowed). 
tive a fixed expense or per diem allowance for travel and related costs, provided, of course, that the allowance is reasonable. The large, publicly-held corporation appears to have encountered little difficulty in taking deductions for its employees' entertainment and travel expenses, ${ }^{26}$ and those relatively few problems which have arisen have usually been resolved at the field-audit level. ${ }^{27}$

In the context of the closely-held corporation, on the other hand, the corporate deduction is frequently and successfully challenged by the Commissioner. ${ }^{28}$ A challenge is made and generally sustained, in whole or in part, whenever the expenditure appears primarily to serve a personal rather than a business purpose, ${ }^{29}$ as when the corporation pays for a yacht, ${ }^{30}$ expensive residence, ${ }^{31}$ hunting expedition ${ }^{32}$ or similar luxury. ${ }^{33}$ In special circumstances, however, the

26. Few decisions have been found involving litigated deductions by large, publiclyheld companies or their executives. For an exceptional case, see Penn v. Robertson, $29 \mathrm{~F}$. Supp. 386 (M.D.N.C. 1939), aff'd, 115 F.2d 167 (4th Cir. 1940) (allowing expenses of vice-president of American Tobacco Company).

27. See note 115 infra.

28. Expense deductions claimed by closely-held corporations are considered the main source of abuse. Expense Accounts: $A \$ 5$ Billion Tax Deduction, and Growing, supra note 1, at 88 (quoting Under-Secretary of the Treasury, Fred C. Scribner, Jr.).

29. See, e.g., Wm. T. Stover Co., 27 T.C. 434, 440-41 (1956) (yacht used for personal pleasure of company's principal stockholder-executive, as well as for business entertainment) ; C. \& C. Beverage, Inc., 13 CCH Tax Ct. Mem. 649, 652-53 (1954) (country club dues of president when desire to play golf was main motivation of membership, even though some company customers belonged to the club and others were entertained there) ; Friedlander Corp., 19 T.C. 1197, 1210-11 (1953), rev'd on other grounds, 216 F.2d 757 (5th Cir. 1954) (rotary club membership dues of company president which he had previously paid for twenty years out of his personal funds); James Schulz, 16 T.C. 401, 406 (1951) (entertainment held to exceed business needs since company had more orders than it could fill); Fred W. Leadbetter, 39 B.T.A. 629, 634 (1939) (cost of five automobiles maintained for personal use of executive and his family); cf. Sam Rosania, Sr., $15 \mathrm{CCH}$ Tax Ct. Mem. 580, 586 (1956) (use of corporate auto for president's personal needs treated as giving president $\$ 500$ additional taxable income). Decisions involving the right of a sole proprietor, a partner or one engaged in professional practice to deduct entertainment expenses are relevant to the closed corporation's right to deduct. See Richard A. Sutter, 21 T.C. 170 (1953) (various categories of physician's entertainment expenses disallowed in whole or in part). But see Olivia de Havilland Goodrich, 20 T.C. 323, 331-32 (1953) (actress's gifts to business associates who would not accept compensation for services held deductible business expenses).

30. American Properties, Inc., 28 T.C. 1100 (1957) (expense of racing boats found sole stockholder's personal hobby); Wm. T. Stover Co., supra note 29 , at $440-41$ (cabin cruiser); Thomas W. Briggs, 15 CCH Tax Ct. Mem. 440, 447-48 (1956) (yacht maintained by taxpayer and his corporation); Richard A. Sutter, supra note 29, at 174 (yacht); Hal E. Roach Studios, 20 B.T.A. 917 (1930) (yacht used partly for business and partly for pleasure).

31. Lanteen Medical Laboratories, Inc., 10 T.C. 279, $288-90$ (1948) (ranch with landscaping, imposing dwellings and golf course).

32. Richard A. Sutter, 21 T.C. 170 (1953). But cf. Sanitary Farms Dairy, Inc., 25 T.C. 463 (1955) (cost of safari allowed as advertising expense).

33. E.g., Paul E. Jackson, 13 CCH Tax Ct. Mem. 1175, 1178 (1954) (mink coat for advertising executive's wife); Haverhill Shoe Novelty Co., 15 T.C. 517 (1950) (wedding of treasurer's daughter); see Jacobs, Glamorous Fringe Benefits, 36 B.U.L. REv. 151 (1956). 
corporation may establish that all or part of a luxury expenditure serves an exclusive corporate purpose. ${ }^{34}$ Even when the corporation is entitled to some deduction-absent exact accounts distinguishing between personal and business costs-the Tax Court is free to substitute its judgment for the taxpayer's in apportioning the expenditure between deductible and nondeductible amounts. ${ }^{35}$

When a corporate disbursement is disallowed as a business expense deduction, complete loss of the deduction is possible whether the corporation is publicly or closely held. Theoretically, a company's direct payment or reimbursement of an executive's personal expenses would appear to be tantamount to additional compensation taxable to the executive and deductible by the company. In one case, involving a closely-held company, the court so held with respect to the disallowed portion of a reimbursement for entertainment and travel expenses. ${ }^{36}$ As a practical matter, however, a disallowed expense deduction will usually not be allowed as a deduction for additional compensation ; $^{37}$ in the case of a closely-held company, it more often is considered a distribution in the nature of a dividend-taxable to the executive but not deductible by the corporation..$^{88}$

34. E. E. Dickinson, 8 B.T.A. 722 (1927) (yacht used for entertainment of business customers held a business asset); cf. Sanitary Farms Dairy, Inc., 25 T.C. 463 (1955). Proof of the executive's dislike of the specific luxury involved may help convince a court that it serves an exclusive business purpose. See Johnson v. United States, $45 \mathrm{~F}$. Supp. 377 (S.D. Cal. 1941), rev'd on other grounds, 135 F.2d 125 (9th Cir. 1943) (membership in Los Angeles country club).

35. One half of the deductions claimed for the use of yachts were allowed in Wm. T. Stover Co., 27 T.C. 434, 440-41 (1956) ; Thomas W. Briggs, 15 CCH Tax Ct. Mem. 440, 447-48 (1956). In Richard A. Sutter, 21 T.C. 170 (1953), one fourth of the deductions were allowed on facts deemed less favorable to the taxpayer. See also George A. Searight, $9 \mathrm{CCH}$ Tax Ct. Mem. 731 (1950) (deduction reduced from $\$ 10,301$ to $\$ 444.42$ ). Compare authorities cited note 87 infra.

36. W. Horace Williams Co. v. Lambert, 56-2 U.S.T.C. I 9839 (E.D. La. 1956), aff'd sub non. Williams v. United States, 245 F.2d 559 (5th Cir. 1957) (disallowing executive's deduction claimed for travel and entertainment equal to his expense allowance but unsubstantiated by detailed records, and charging amount to him as income).

37. See Joseph Morgenstern, P-H 1955 T.C. Mem. Dec. If 55086 (depreciation of automobile maintained by corporation for benefit of principal stockholder-executive held not intended or treated by corporation as compensation to executive); $c f$. Marvin T. Blackwell, $15 \mathrm{CCH}$ Tax Ct. Mem. 962, 968-71 (1956) (corporation failing to raise argument that disallowed expenses were additional compensation) ; Hal E. Roach Studios, 20 B.T.A. 917 (1930) (same). But see Rodgers Dairy Co., 14 T.C. 66, 73 (1950) (amount disallowed as automobile expense would represent additional compensation to executive who had personal use of automobile). See note 115 infra.

38. See B. F. Crabbe, 14 CCH Tax Ct. Mem. 1305, 1308-10 (1955) (disallowed travel expense reimbursement held dividend to president of closely-held corporation); Louis Greenspon, 23 T.C. 138, 148-52 (1954), aff'd, 229 F.2d 947 (8th Cir. 1956) (corporate expenses in improving stockholder-executive's farm, which was his home but little used for business entertainment, held nondeductible by corporation and in nature of corporate distribution taxable to executive as income) ; cf. Byers v. Commissioner, 199 F.2d 273, 275 (8th Cir. 1952) ; 58th St. Plaza Theatre, Inc. v. Commissioner, 195 F.2d 724 (2d Cir. 


\section{The Executive's Tax Status}

\section{Receipt of Income}

If expenses incurred by an executive are proper business expenses of his corporation, their payment by the corporation clearly does not constitute compensation to the executive, whether corporate payment is made directly or is reimbursed to the executive who initially made the payment. ${ }^{39}$ To qualify for this treatment, however, the executive must be able to demonstrate that the expense paid or reimbursed was a business expense of the corporation-not an expense of his own. Adequate recording of expenses by the corporation indicating amounts and corporate purposes, and reimbursement based upon the presentation of adequate bills or vouchers, will of course facilitate this ain. If the executive is to be reimbursed for the partial use in company business of a home, club, automobile or airplane, an appropriate formula should be evolved to substantiate the cost attributable to such use. ${ }^{40}$ Absent verifying records of this nature, expenses reimbursed to the executive may be taxed to him wholly or partially as income. ${ }^{41}$

As distinguished from payment or reimbursement of specific expenses, a flat expense allowance must be reported as gross income in the executive's income tax return; business expenses paid by him from the allowance may then be deducted in computing adjusted gross income. ${ }^{42}$ Although such expenses might

1952) ; Flora Regensburg, 1 CCH Tax Ct. Mem. 925 (1943), aff'd, 144 F.2d 41 (2d Cir.), cert. derried, 323 U.S. 783 (1944). But cf. Joseph Morgenstern, supra note 37 (nondeductible payment by corporation not treated as dividend to stockholder-executive).

39. The amounts so paid or reimbursed to the executive need not be included in his gross income. Eitingon-Schild Co., 21 B.T.A. 1163, 1175-76 (1931) ; Julius Forstmann, 6 B.T.A. 21. (1927). For a nominal exception in the case of traveling expense, see note 103 infra and accompanying text.

40. The difficulties involved in allocating business and personal costs without ascertainable formulas leave the courts with little evidence on which to base their decision. See Willard I. Thompson, 15 T.C. 609 (1950); McDonald, Travel and Entertainment Expenses, in ENCYCLOPEDIA of TAX PRoCEdUREs 451, $460 \mathrm{n} .19$ (1956) (collecting cases). See also the contract clause quoted note 20 supra. For suggestions about records that should be kept and workable formulas, see Dendy, How To Get the Maximum Deductions From Compensation, N.Y.U. 8th Inst. on Fed. TAX. 1052, 1055 (1950); Green, How To Handle Expense Accounts of Corporate Executives, 8th id. at 564, 566-68; Hayes, Deductions for Travel and Entertainment Expense, 4 ARTHUR Young J. 1 (1957); Hemmings, Technical Rules Underlying Current Furor Over Deductibility of $T \& E$ Expenses, $8 \mathrm{~J}$. TAxatroN 2 (1958) ; Osmond, The Corporate Executive and the Business Expense Deduction, 33 TAXEs 68 (1955); Perkins, Recommendations for Preventing Disallowance of Expenses for Travel and Entertainment, 4 J. TAXation 10 (1956); Stuart, Social Club Dues and Expenses, 31 TAXES 69,71-72 (1953). When the use of facilities is contemplated and no formula for payment is feasible, payment for the facilities has been combined with reimbursement for entertainment expense. See Washington \& Rotrischild app. E; cf. Parker, A Check List of Deductions for the Professional Taxpayer, 29 N.Y.S.B. Bul. 141 (1957).

41. B. F. Crabbe, $15 \mathrm{CCH}$ Tax Ct. Mem. 216, 219-21 (1956) ; B. F. Crabbe, $14 \mathrm{CCH}$ Tax Ct. Mem. 1305, 1308-10 (1955) (same for different years); Victor Cooper, \& CCH Tax Ct. Mem. 689, 697 (1949).

42. See Proposed U.S. Treas. Reg. 103, § 19.1, 23 Feb. Reg. 1698 (1958) ; cf. Walter I. Geer, 28 T.C. 994 (1957) (Georgia state court judge's contingent travel allowance of $\$ 200$ per month held income). See also U.S. Treas. Reg. 118, § 39.23(a) (2) (1953). 
reasonably be considered unreimbursed employee expenses deductible only from adjusted gross income on the theory that the corporation, having designated an enlarged area of executive responsibility, is merely providing additional salary with which the executive may perform his expanded function, the Tax Court has preferred to view the transaction as a prepayment for corporate expenses that the executive is expected to incur. Again, the burden rests with the executive as taxpayer to prove that he incurred the expenses in the company's interest and that the amount deducted corresponds to his actual disbursements. ${ }^{43}$

Expenditures involving transactions that are illegal, improper or otherwise against public policy should not be deemed "ordinary and necessary" business expenses. ${ }^{44}$ Entertainment of or gifts to a public official should thus be

43. Walter I. Geer, supra note 42; Ned Wayburn, 32 B.T.A. 813 (1935); Green, supra note 40 , at 566 . An unqualified commitment to pay a specific expense allowance with no requirement of an accounting makes it necessary for the corporation to include the expense allowance in its information returns. U.S. Treas. Reg. 118, $\$ 39.147-2$ (1953) (forms 1096 and 1099); see Mim. 5947, 1945 Cum. Burc. 235. As to social security taxes on expenses advanced or reimbursed, see U.S. Treas. Reg. 106, $\S 402.227$ (b) (2) (1940), as amended, T.D. 5502, 1946-1 Cums. Bull. 250, 253, T.D. 5566, 1947-2 Cum. Buls. 148, T.D. 5805, 1950-2 Cuar. Bull. 112; U.S. Treas. Reg. 107, $\$ 403.227$ (b) (2) (1940), as amended, T.D. 5502, 1946-1 Cum. Bull. 250, 254, T.D. 5566, 1947-2 Cum. BuLr. 148, T.D. 5805, 1950-2 Cun. Bulz. 112, T.D. 5905, 1952-1 Cun. Bulr. 173, 183-84; see also Mim. 6547, 1950-2 CUM. BULL. 113. In the case of executive compensation, the amounts subject to these taxes are relatively so small that they are significant, apart from bookkeeping, only in special circumstances, as when the executive is first employed toward the end of the year.

44. For cases disallowing expenditures as per se illegal, see R. E. L. Finley, 27 T.C. 413, 423-24 (1956) (liquor purchased for business entertainment in prohibition state); Fred D. Newman, P-H 1952 T.C. Mem. Dec. If 52267 (cost of whisky samples given to employees of state liquor store in violation of state law) ; Lorraine Corp., 33 B.T.A. 1.158, 1166 (1936) (liquor purchased for entertainment purposes during Prohibition). Expenditures not illegal in themselves are generally disallowed when their deduction would frustrate national or state policies. See Commissioner v. Heininger, 320 U.S. 467,473 n.8 (1943) (citing cases). For applications of this rule in particular contexts, see Wm. T. Stover Co, 27 T.C. 434, 443-45 (1956) (disallowing deduction for compensation paid state hospital director as consultant by taxpayer who sold supplies to the hospital); see also Duval Motor Co., 28 T.C. 42,54 (1957) (disallowing cost of gift certificate given to state highway patrol director by dealer selling cars to the highway patrol); Cecil I. Haas, P-H 1953 T.C. Mem. Dec. If 53322, at 1007 (holding expenditures for the entertainment of public officials to be contrary to public policy and therefore nondeductible). In order for expenditures to be disallowed as against public policy, the federal or state policy must be sharply defined. Compare Lilly v. Commissioner, 343 U.S. 90 (1952) (allowing optometrist's deduction of payments to physicians referring their patients to the optometrist, where state statute enacted after payments had been made prohibited such conduct), with Textile Mills Securities Corp. v. Commissioner, 314 U.S. 326 (1941) (upholding Treasury regulation disallowing deduction of lobbying expenses although Congress had not declared such expenditures illegal). When federal tax law recognizes as a "business" an activity illegal under state law, legitimate expenses of that business are deductible. See Commissioner v. Sullivan, 356 U.S. 27 (1958), affirming 241. F.2d 46 (7th Cir. 1957) (rent and wages of bookmaker).

On the relationship of deductibility and public policy generally, see Comment, The Effect of Lilly on the Disallowance of Expense and Loss Deductions Deemed Contrary to Rublic 
disallowed as a tax deduction, whether claimed by the executive making the disbursement or by his employer.

\section{Deductions from Income}

Individual or Corporate Deduction? An executive, by virtue of his position, may make expenditures which he considers to be ordinary requirements of his occupation and for which no reimbursement is contemplated or received. Since a corporate executive is usually deemed in the "trade or business" of being an executive, ${ }^{45}$ compensation received from his employment is income from a trade or business, and ordinary and necessary expenses required by his employment are deductible as business expenses. ${ }^{46}$ But it is equally well-established that the executive as taxpayer may not take deductions belonging to another taxpayer-the corporation which employs him. ${ }^{47}$ What will ultimately be held to be the executive's business expense and what the corporation's cannot always be known in advance; and a shadowy borderland remains in which a business expense deduction may be lost both by the corporation and the executive. The corporation cannot take the deduction except as a salary payment for the obvious reason that it did not incur the expense. The executive may be denied the deduction if he cannot persuade the tax authorities or the courts that the expense was one which he was required or expected to bear by reason of his position as a corporate officer. ${ }^{48}$

Policy, 41 MarQ. L. Rev. 305 (1957); Notes, 51 Colun. L. Rev. 752 (1951), 38 VA. L. REv. 771 (1952).

45. See Folker v. Johnson, 230 F.2d 906 (2d Cir. 1956) (corporate executive held in "trade or business" for loss-carryback purposes); Samuel H. Ranson, Jr., 11 CCH Tax: Ct. Mem. 699, 701 (1952) (same); see also Schmidlapp v. Commissioner, 96 F.2d 680, 681-82 (2d Cir. 1938) ; cf. Anders J. Lagreide, 23 T.C. 508, 512-13 (1954) (teacher held engaged in "trade or business" for loss-carryback purposes).

A corporate executive has been allowed to deduct compensation paid for legal or other professional services on the ground that he is engaged in a trade or business. Hochschild v. Commissioner, 161 F.2d 817 (2d Cir. 1947) ; Foss v. Commissioner, 75 F.2d 326, 327-28 (1st Cir. 1935). See also Cohn v. Columbia Pictures Corp., N.Y. County Clerk's Index No. 9038/1950 (N.Y. Sup. Ct. 1950) (allegedly improper payment by corporation of executives' legal expenses). But cf. Fred F. Fischer, 1947 P-H T.C. Mem. Dec. If 47131 (expenses held those of corporation, not of executive); Hal E. Roach, 20 B.T.A. 919 (1930) (same).

46. Schmidlapp v. Commissioner, supra note 45. However, expenses incurred in organizing a business by one who later becomes an executive in that business are not deductible. Frank B. Polachek, 22 T.C. 858, 862-63 (1954); Morton Frank, 20 T.C. 511 (1953) ; Dwight A. Ward, 20 T.C. 332, 343-44 (1953).

47. E.g., compare Hal E. Roach Studios, 20 B.T.A. 917 (1930), with Hal E. Roach, 20 B.T.A. 919 (1930). Cf. authorities cited note 48 infra.

48. Rev. Rul. 502, 1957 Int. Rev. Bull. No. 43, at 15; see Penn v. Robertson, 29 F. Supp. 386 (M.D.N.C. 1939), aff'd, 115 F.2d 167 (4th Cir. 1940) (annual travel and entertainment expenses of vice-president of American Tobacco Co., averaging $\$ 13,500$, held deductible since in proper relationship to salary average of over $\$ 450,000)$; Hal E. Roach, stpra note 47. See also Schmidlapp v. Commissioner, 96 F.2d 680 (2d Cir. 1938) ; Cohan 
When the executive receives a fixed expense allowance to cover a stipulated type of expenditure, he can more readily prove the expenditure to have been on behalf of the corporation. Here, clearly, the corporation expects, if it does not require, that the executive make the stipulated expenditure in discharging the duties of his office. Although expenditures like luncheons purchased by a sales executive for customers may be in the corporation's interest, the corporation has relieved itself from incurring them by asking the executive to do so. Such payments will in appropriate circumstances be deductible by the executive as necessary and ordinary expenses. ${ }^{49}$ In the absence of a flat expense arrangement, a corporate resolution ${ }^{50}$ or policy statement ${ }^{51}$ will go far toward meeting the executive's burden of proof..$^{62}$ Without such corporate expressions of executive responsibility, the executive may find that expenses which he considered

v. Commissioner, 39 F.2d 540 (2d Cir. 1930) ; Lempert, Who Can Deduct a Bisiness Expense?, 11 TaX L. Rev. 433, 436-41 (1956) ; Note, 66 HARv. L. Rev. 1508, 1509-11 (1953).

49. "Reimbursement for such expenses to the corporation officer . . . would tend to indicate that they are a necessary expense of his office." But "the presence of such evidence does not conclusively determine that the expenses are deductible ...." Rev. Rul. 502, 1957 Int. Rev. Bult. No. 43, at 15, 17. See Arthur Brookfield, $15 \mathrm{CCH}$ Tax Ct. Mem. 247 (1956) (deduction allowed to extent of entertainment expense reimbursement but denied for expenses in excess thereof) ; Green, supra note 40, at 565-66; Lempert, supra note 48, at 437 . It has been said in justification of denying the deduction, that the government should not reimburse the executive indirectly, when the employing corporation has refused to do so directly. Nathaniel J. Hess, 24 B.T.A. 475, 479-80 (1931). Cf. Harry Boverman, 10 T.C. 476, 477-81 (1948) (insurance manager denied déduction for prizes awarded agents because prohibited by his employment contract).

50. An example of such a provision, in the form of a resolution of the Board of Directors, follows:

RESOLvED, that the Board recognizes that the successful operation and management of the Company's business has required and will continue to require [name] to expend, in the discharge of his duties as [position], substantial sums for the entertainment of various persons and representatives of companies with whom the Company has or might expect to have business relationships. For any such entertainment expenses which are not susceptible to the usual accounting, [name] shall not be entitled to reimbursement, it being understood that his compensation has been determined with a view to enabling him to incur such type of expense on behalf of the Company out of such compensation.

51. See CaSey \& Rothschild exh. 170 (Time, Inc. memorandum to salesmen: "Time salesmen are paid high salaries because selling is not a routine job. . . There are many expenses incidental to selling which the salesman is not expected to recover from the Company on top of his salary").

52. Rev. Rul. 502, 1957 INT. Rev. Bull. No. 43, at 15, was issued in response to a request for advice as to whether a corporate resolution or other statement embodied in the minutes would meet the executive's burden of proving travel or entertainment expenses to have been necessary and ordinary expenses of his business as a corporation executive. The quotation therefrom in note 49 supra applies to a "resolution requiring the assumption of such expenses by" the executive. However, the absence of such evidence is not conclusive. For other acceptable evidence of a corporate policy requiring executives to meet entertainment expenses from their own pockets as a function of their corporate office, see Albert L. Sanderson, 16 CCH Tax Ct. Mem. 105 (1957) (salary of vice-president increased to enable him to pay club dues in accordance with trust company's personnel policy). 
incidental to his employment are not deductible on his income tax return. ${ }^{\text {.3 }}$ Morever, if the employing corporation has a reimbursement policy for the particular kind of expense which the executive has incurred, a deduction by the executive may be barred if he has failed to seek reimbursement. By providing for reimbursement, the employing corporation has assumed responsibility for the expenditure and has, in effect, denied that the executive was required to bear it out of his own pocket. ${ }^{54}$

Personal or Business Expense? As a general rule, the expenses of an executive for travel, for entertainment, for services which are necessary and ordinary incidents of his "business" as a corporate executive, are considered business rather than personal expenses of the executive and hence deductible by him.

Expenses for travel and transportation include not only unreimbursed amounts spent in connection with trips away from home ${ }^{55}$ but also local trans-

53. Samuel Saffan, $16 \mathrm{CCH}$ Tax Ct. Mem. 822 (1957) (cost of using own automobile in corporate business by officer-stockholder disallowed); William and Jeanne Auerbacher, 15 CCH Tax Ct. Mem. 1147, 1150 (1956) (incidental effect on morale of department store buyer's gifts to employees working under her, not required by store policy, was insufficient business reason to constitute gifts a business deduction) ; Harry Kahn, 26 T.C. 273 (1956) (travel and entertainment expenses incurred by substantial stockholder in year when corporation had a loss) ; Arthur Brookfield, $15 \mathrm{CCH}$ Tax Ct. Mem. 247, 253 (1956) (club dues) ; Charles N. Kimball, $14 \mathrm{CCH}$ Tax Ct. Mem. 1011 (1955) (disallowing office and travel expenses of president of gold mining company); Jacob M. Kaplan, 21 T.C. 134, 145-46 (1953) ; James M. Hawkins, 20 T.C. 1069, 1075 (1953) ; Andrew Jergens, 17 T.C. 806, 811 (1951) ; Wilbur H. Clayton, 7 CCH Tax Ct. Mem. 349 (1948) (cost of entertaining employees to allay their discontent disallowed) ; Cecil P. Stewart, 5 CCH Tax Ct. Mem. 229, 233-34 (1946) (entertainment expenses incurred by corporation's president disallowed) ; Hal E. Roach Studios, 20 B.T.A. 917 (1930) ; Abraham W. Ast, 9 B.T.A. 694 (1927) ; Franklin M. Magill, 4 B.T.A. 272 (1926). See also A. Augustus Low, 3 CCH Tax Ct. Mem. 859 (1944), aff'd sub nom. Low v. Nunan, 154 F.2d 261 (2d Cir. 1946) (unpaid corporate officer held not engaged in business and hence not entitled to business deductions).

When the expense is incurred by the executive of his own accord to maintain good relations with his subordinates or to hire a personal assistant to render business services directly to him, not the corporation, the executive may take a business expense deduction for the amount thus spent. William and Jeanne Auerbacher, silpra; Harold A. Christensen, 17 T.C. 1456 (1952) (field manager entertained salesmen supervised by him); John Sidney Thompson, $9 \mathrm{CCH}$ Tax Ct. Mem. 694 (1950) (salary of assistant employed and paid by president whose compensation consisted of commissions). Cf. Arthur Brookfield, supra (district sales manager denied deduction since, contrary to Christensen, he could not show dependence of his compensation, including participation in bonus plan, upon efforts of sales force he supervised). But see James D. Robinson, 45 B.T.A. 39 (1941) (employee's service rendered to corporation).

54. Horace E. Podems, 24 T.C. 21 (1955) (Internal Revenue agent denied deduction for automobile expense for which the government would have reimbursed him on submission of appropriate request; difference between the actual cost of his travel and the reimbursement which he could have received allowed).

55. E.g., Mary Sachs, 11 CCH Tax Ct. Mem. 882, 885 (1952) (expenses allowed in ful1) ; see Frank L. Kluckhohn, 18 T.C. 892 (1952) (expenses allowed in part, taxpayer having lost his records). The executive's traveling expense to and from his place of business is generally not deductible, even though his home may be in a suburb or in another city. Commissioner v. Flowers, 326 U.S. 465 (1946). When the employing corporation 
portation costs; both are deductible from the executive's gross income and are thus available to him in addition to the standard deduction. ${ }^{56}$ Such expenses are deductible, furthermore, whether public transportation facilities or the executive's own automobile or airplane is used..$^{67}$ Hence, so long as disbursements are made only for items which are reasonably necessary to fulfillment of business purposes, ${ }^{58}$ the executive will be relieved from tax on all amounts expended during travel. But when some of the expenses incurred during business travel are traceable to nonbusiness motives, the Commissioner will deny a deduction for at least those expenses. Costs of business travel will not be held nondeductible simply because some opportunity exists for recreation, such as sightseeing or nonbusiness entertainment, in connection with the trip; but the cost of these incidental personal activities should be separately allocated and will be nondeductible. ${ }^{59}$ On the other hand, if the primary purpose of the trip is personal, as for a vacation, its entire cost will be nondeductible, even though some business activities, such as attending lectures or visiting a company plant, may occur during its course. ${ }^{60}$

With regard to business entertainment, deductible expenses have included the cost of food and liquor, ${ }^{61}$ tickets for theater performances and other public enter-

has two or more places of business and the executive travels between the one where his home is located and another, his traveling expenses may be deductible. Joseph H. Sherman, Jr., 16 T.C. 332 (1951). As to whether such travel "while away from home," INT. REv. CoDE of 1954, $\$ 162$ (a) (2), is limited to overnight travel, compare the Commissioner's view in Your Federal Incone TAX Forms 6 (1957), with Chandler v. Commissioner, 226 F.2d 467 (1st Cir.), reversing Douglas A. Chandler, 23 T.C. 653 (1955). For a similar decision, see Emmert v. United States, 146 F. Supp. 322 (S.D. Ind. 1955). See also Carroll B. Mershon, 17 T.C. 861 (1951) ; Kenneth Waters, 12 T.C. 414 (1949), both decided under the 1939 Code. The Commissioner, contrary to the foregoing decisions, adheres to the view that travel "while away from home" means travel overnight. See Comment, 36 B.U.L. Rev. 139 (1956). The actual cost of local business transportation, whether by public or private facilities, is deductible by the executive from his gross income. INT. REv. CODE of 1954, §62(2)(B).

56. Id. $\$ 62(2)$; Rev. Rul. 502, 1957 INT. Rev. BuLl. No. 43, at 15. An example of local transportation costs are cabs to and from the airport.

57. Lang v. United States, 134 F. Supp. 214 (N.D. Ga. 1955) ; John A. Lovelady, 15 CCH Tax Ct. Mem. 1498 (1956) ; William and Jeanne Auerbacher, 15 CCH Tax Ct. Mem. 1147, 1151-52 (1956) (semble) ; Marvin T. Blackwell, 15 CCH Tax Ct. Mem. 962, 968-71 (1956) (automobile expense, including insurance, allowed in part) ; Seymour Wetzler, 11 CCH Tax Ct. Mem. 1001 (1952). Many of these cases involve partial disallowances of deductions claimed for automobile expenses based on findings that personal use was greater than that claimed by the executive.

58. For a discussion of the requirement of "reasonableness" as applied to travel, see McDonald, supra note 40 , at 455-57.

59. Rev. Rul. 168, 1956-1 CuMr. Bull. 93, at 93-94.

60. Id. at 94 . When the executive travels on business but is accompanied by his family, he can charge hotel accommodations at the single rate to business expense. Ibid. See McDonald, supra note 40 , at 457 . For deductibility of travel costs of a wife accompanying her husband-executive to conventions or on business trips for the purpose of rendering business services to him, see notes 73-74 infra and accompanying text.

61. Cf. Louis Reinheimer, $16 \mathrm{CCH}$ Tax Ct. Mem. 56, 60 (1957) ; Richard A. Sutter, 21 T.C. 170 (1953); Charles S. Guggenheimer, 18 T.C. 81, 85-86 (1952); Harold A. 
tainment, ${ }^{62}$ and gifts to business associates or employees. ${ }^{63}$ Also held deductible have been the cost of dining clubs, payments made for country club memberships $^{64}$ and expenses of maintaining seasonal residences, yachts, ${ }^{65}$ hunting lodges ${ }^{66}$ and other facilities used for business entertainment. ${ }^{67}$ Sustaining the

Christensen, 17 T.C. 1456 (1952) ; Osmond, supra note 40, at $70 \mathrm{nn} .19-20$ (collecting cases). But cf. R. E. L. Finley, 27 T.C. 413, 423-24 (1956) (illegal liquor purchase disallowed as deduction) ; Rev. Rul. 307, 1955-1 Cum. Burl. 22 (same; citing Lilly v. Commissioner, 343 U.S. 90 (1952)).

62. Maurice E. Harvey, $12 \mathrm{CCH}$ Tax Ct. Mem. 1358, 1362-63 (1953) (Kentucky Derby, football games, Mardi Gras in Mobile, Alabama); Harold A. Christensen, supra note 61 .

63. Marvin T. Blackwell, 15 CCH Tax Ct. Mem. 962, 972-73 (1956) ; Olivia de Havilland Goodrich, 20 T.C. 323, 331-32 (1953); Harold A. Christensen, 17 T.C. 1456 (1952).

64. Johnson v. United States, 45 F. Supp. 377 (S.D. Cal. 1941), rev'd on other grounds, 135 F.2d 125 (9th Cir. 1943) ; Charles S. Guggenheimer, 18 T.C. 81, 85-86 (1952) (both involving lawyers); see also Albert L. Sanderson, 16 CCH Tax Ct. Mem. 105 (1957) (trust company vice-president) ; Kenneth Blanchard, $12 \mathrm{CCH}$ Tax Ct. Mem. 550, 557-58 (1953) (physician). The Tax Court tends to disallow a deduction for club dues unless a demonstrably successful business purpose or a requirement of membership imposed by the employing corporation is shown. Ibid. (physician's club dues deductible only to the extent that business use of club specifically shown); Norman M. Hussey, $11 \mathrm{CCH}$ Tax Ct. Mem. 141 (1952) (partial deduction allowed to lawyer demonstrating use of club to build practice). See William and Jeanne Auerbacher, 15 CCHI Tax Ct. Mem. 1147, 1151 (1956) (holding that petitioner cannot argue generally, but must show whom he entertained at club) ; Arthur Brookfield, $15 \mathrm{CCH}$ Tax Ct. Mem. 247, 253 (1956) ; Mary Sachs, $11 \mathrm{CCH}$ Tax Ct. Mem. 882, 890 (1952) (initiation fee paid to club may also be held nondeductible as in the nature of capital expense). Dues to business organizations, such as chambers of commerce, are generally deductible. See, e.g., Smith-Bridgman \& Co., 16 T.C. 287 (1951); see also Mary Sachs, supra at 890 . But see Arthur S. McKenzie, 11 CCH Tax Ct. Mem. 437,438 (1952) (chamber of commerce dues not considered a proper business expense of a Veterans Administration clerk-typist). See also Osmond, supra note 40, at 70-71 n.23; Stuart, stupra note 40.

65. Wm. T. Stover Co., 27 T.C. 434, 440-41 (1956); Thomas W. Briggs, 15 CCH Tax Ct. Mem. 440, 447-48 (1956); Richard A. Sutter, 21 T.C. 170 (1953); Charles J. McLannan, 4 CCH Tax Ct. Mem. 672 (1945).

66. S. P. McCall, $13 \mathrm{CCH}$ Tax Ct. Mem. 446, 450 (1954); Walter O. Kraft, 8 CCH Tax Ct. Mem. 606 (1949).

67. Thomas W. Briggs, 15 CCH Tax Ct. Mem. 440, 448, 452 (1956) (corporation with headquarters in Tennessee allowed $50 \%$ of deduction claimed for rent of New York City apartment used for entertainment of customers, press and employees). But see Estate of Edwin Raymond Fisher, 11 CCH Tax Ct. Mem. 607, 610 (1952) (disallowing, as personal expense, deduction for additional rental of higher-priced apartment to which corporation's customer-relations man moved, ostensibly to better entertain actual and prospective customers, notwithstanding taxpayer's motive) ; Cecil P. Stewart, $5 \mathrm{CCH}$ Tax Ct. Mem. 229, 232-33 (1946) (disallowing expense deduction for loss on stock in co-operative apartment building claimed to be used for entertaining customers).

Other deductions of varied character arising from the variety of business life have been allowed from time to time. See, e.g., Arthur Brookfield, 15 CCH Tax Ct. Mem. 247, 254 (1956) (subscription to technical journals). To deduct the cost of clothing, a clear business purpose for its purchase must be shown. Wilson John Fisher, 23 T.C. 219, 225 (1954) (musician playing at hotels); Olivia de Havilland Goodrich, 20 T.C. 323, 329 (1953) 
latter category of deductions has, however, proved difficult, since facilities such as clubs, yachts and summer homes are not often exclusively maintained for business use. Executives involved in such cases have tended to disregard their personal use in preparing their returns or have overestimated their business use. ${ }^{68}$ From the difficulty of determining the relative quanta of business and personal use, especially in instances where the taxpayer's ownership of the facility appears dependent on the indirect public subsidy inherent in a tax deduction, arise many of the contested, often sensational, tax cases.

The personal-business dichotomy, epitomized by the yacht cases, has been the basis of controversy in homelier contexts. Thus, the Tax Court has questioned the extent to which ordinary living expenses incurred in connection with business entertainment or travel can be deducted. ${ }^{69}$ Here, it is apparent that the business deduction reduces the burden of expenses, all or part of which must otherwise have been incurred by the taxpayer as a personal expense. Every executive and his family must eat; but should the entire cost of a dinner, often more elaborate than usual, become a tax deduction because a business guest is entertained at the table? Or should the deduction be limited to the amount attributable to the guest's share of the meal or to the shares of both the guest and the executive? Or should a deduction for the host be limited to the difference between the cost of his ordinary dinner and the more elaborate dinner of which he partakes because of the business guest? To dismiss the whole matter as de minimis is to blur the distinction between personal and business expenses to the point where a substantial portion of the executive's daily living expenses may become tax free by way of the business entertainment deduction. ${ }^{70}$ As a practi-

(motion picture actress). A taste for expensive clothing cannot be indulged. William and Jeanne Auerbacher, 15 CCH Tax Ct. Mem. 1147, 1150-51 (1950); Paul E. Jackson, 13 CCH Tax Ct. Mem. 1175, 1178 (1954). Office expenses, which clearly are deductible, seem to have caused little litigation. See Parker, supra note 40. But see Paul Bakewell, Jr., 23 T.C. 803 (1955) (lawyer's hearing aid not a deductible business expense).

68. See, generally, cases cited notes 64-66 supra.

69. Richard A. Sutter, 21 T.C. 170 (1953). Emphasizing the presumption that personal living expenses apparently remain nondeductible under INT. REv. CODE of 1954, $\$ 262$, so as to prevent taxpayers from shifting their burden of paying personal expenses to the public, the Tax Court said: "Running through most of the contested items is the stubborn thread of a single problem which has never apparently been squarely and expressly passed upon. ... When a taxpayer in the course of supplying food or entertainment or making other outlays customarily regarded as ordinary and necessary includes an amount attributable to himself or his family, such as the payment for his own meals, is that portion of the expenditure an ordinary and necessary business expense on the one hand or a nondeductible personal item on the other?" 21. T.C. at 173. The Tax Court concluded that meals at home for oneself and one's dependents remain a nondeductible personal expense, notwithstanding the presence of business guests. It would follow that the expense of meals away from home, even when involving a business engagement, should, at most, be deductible only in the amount greater than the cost of ordinary meals at which no business guest is present. The entire cost of the luncheons at chamber of commerce meetings was disallowed in Sutter.

70. See Morgan, Expense Account passim (1958), discussed note 2 supra. But cf. Bryson \& Lefevre, Tax Aspects of Executives' Compensation 16 (Practicing Law Inst. 1955). 
cal matter, a Tax Court decision raising these questions has remained more of a warning than a real limitation on deductions. ${ }^{71}$

The final category of business deductions involves services for which the taxpayer is required to pay out of his own pocket. Examples are telephone calls, telegrams ${ }^{72}$ and stenographic assistance on a business trip. Since secretarial services are costly, the executive may prefer to have his wife accompany him on the trip in order to serve as a stenographer, typist or social secretary. If bona fide business services of this kind are rendered by the executive's wife, the cost of her travel may be deducted as a business expense. ${ }^{73}$ The wife's services, however, are usually nominal; and expenditures incurred by the executive in taking her on a business trip are ordinarily held to be personal and nondeductible, even though the wife helps to entertain business customers or otherwise proves incidentally useful. ${ }^{74}$ The test appears to be whether the wife has discharged a function for which the executive would otherwise have had to pay.

Questions of Proof. Assuming that the executive has incurred business rather than personal expenses for which he can claim a deduction on his income tax return, he still must be prepared to prove the actual amount of the expenses and their payment in the tax year for which the deduction is claimed. Especially in closely-held corporations, where absence of effective corporate control over the

71. For an application of the Sutter principles, see Charles O. Gunther, Jr., $13 \mathrm{CCH}$ Tax Ct. Mem. 984, 991 (1954).

72. Ernest Huddleston, $13 . \mathrm{CCH}$ Tax Ct. Mem. 395 (1954) (allowing a truck driver deduction for one half of the cost of a telephone which his employer required him to have in his home) ; Julius C. Henricks, 8 CCH Tax Ct. Mem. 993 (1949) (cost of telephone calls and telegrams of an advertising solicitor held deductible).

73. Rev. Rul. 168, 1956-1 Cum. Bull. 93; Rev. Rul. 57, 1955-1 Cun. Bull. 315; cf. Walkup Drayage \& Warehouse Co., 4 CCH Tax Ct. Mem. 695, 703 (1945) (corporation allowed to deduct expenses of president's wife, formerly his secretary, who accompanied him on business trip). "There was a time when a man took along his secretary on a business trip and said she was his wife. . . Nowadays, for income tax expense reasons, he takes his wife and says she's his secretary." N.Y. Times, Feb. 16, 1958, p. 9, col. 6 (quoting the Journal of the British Income Taxpayers' Society); see Bougher, Dedictibility of Expenses of Wife on Business Trip, 10 Bus. Law. 54 (1955) ; Livingston, Wives Can Be Deductible, Washington Post, May 2, 1956, p. 27, cols. 3-4.

74. Mere typing of an occasional business letter or attendance at business luncheons and receptions with her husband is not sufficient business purpose to justify a deduction. These incidental services do not establish a business need for her presence at conventions or other business engagements of her husband away from home. See Rev. Rul. 168, 1956-1 Cum. Bulx. 93; Rev. Rul. 57, 1955-1 Cum. Bull. 315. For Tax Court decisions disallowing a wife's travel expenses on the same theory expounded by these rulings, see B. F. Crabbe, 15 CCH Tax Ct. Mem. 216, 219-21 (1956); Axel S. Stokby, $12 \mathrm{CCH}$ Tax Ct. Mem. 761, 766 (1953). Compare ibid. with John C. Thomas, CCH BTA Mem. Dec. 10622-A (1939) (allowing travel expense deduction for wife acting as husband's singing coach and foreign language elocution teacher on tours). See Andrews, Whose Income Tax Are You Paying?, Am. Mag., Feb. 1954, pp. 21, 105 (former Commissioner of Internal Revenue writes that wives may be included as part of a business expense at "a dinner for promotional purposes to which other wives are invited" but that clothes for such a dinner would not be deductible). 
taxpayer's expenditures casts suspicion on claimed deductions, proof of business travel or entertainment is often so vague as to raise a serious question whether the claimed expense was actually incurred or, if incurred, whether it served a business purpose. When only nebulous taxpayer records indicate the business purpose supporting the deduction, it will be disallowed on audit and the disallowance will be sustained on appeal..$^{75}$ In the case of the closed corporation, absent carefully prepared records, only the general testimony of the stockholder-executive will normally be available to substantiate the facts on which the deduction is based, and evidence insufficient to establish the executive's deduction is also insufficient to sustain a corporate deduction. ${ }^{76}$

The quantum of evidence that will be required to sustain the taxpayer's burden of proof cannot always be anticipated. But the executive can follow simple practices which will aid his case before the taxing authorities. ${ }^{77}$ From a travel itinerary showing places visited and modes of travel, transportation costs can be reconstructed. Hotel bills, if preserved, will indicate not only the cost of the lodging but also incidental charges for telephone calls, room service and, in many instances, the hotel's restaurant charges. If credit and "club" cards are used in charging expenses, bills rendered by the "clubs" may show the amounts spent by the executive as well as the time and place of the expenditure. The cost of gas and oil consumed in travel by private automobile can be calculated with reasonable accuracy from records of mileage traveled.

While documentary evidence of this type will provide the strongest support for claimed deductions, the Commissioner has recognized that absolute certainty is unattainable and that a taxpayer cannot be "required to secure, retain, and produce receipts for each meal and for each night's lodging." Accordingly, the "Revenue Service allows considerable latitude with respect to recordkeeping or evidence tending to prove [travel and entertainment] . . expenses."78 For example, the Commissioner will apparently consider a diary-type expense $\log$ as probative of travel and entertainment expenses incurred by the executive. ${ }^{70}$ Details of engagements noted in business diaries or desk calendars and memoranda dictated while facts are fresh in mind will also help to substantiate

75. E.g., Dave Rubin, 26 T.C. 1076, 1081-82 (1956); M. L. Cottingham, 15 CCH Tax Ct. Mem. 987, 991 (1956); Gordon Pascal, 15 CCH Tax Ct. Mem. 434 (1956); B. F. Crabbe, supra note 74 , at 219-21.

76. See M. L. Cottingham, supra note 75, at 991-92; B. F. Crabbe, $15 \mathrm{CCH}$ Tax Ct. Mem. 216, 219-21 (1956) ; Oscar J. Cahn Corp., 13 CCH Tax Ct. Mem. 195 (1954) (taxpayer claimed deduction of $\$ 73,798.51$; Commissioner allowed $\$ 19,164.51$ which the $\operatorname{Tax}$ Court increased to $\$ 36,000)$; cf. Proposed U.S. Treas. Reg. 103, $\S 19.1-4,23$ FED. REg. 1698 (1958) (calling for "approximations based upon reliable secondary sources").

77. See U.S. Income Tax Form 2106 (Official Worksheet) ; LASsER, TAx Ard Records and Appointarent Book (1958).

78. Rev. Rul. 497, 1954-2 CuMr. Bulı. 75, 76.

79. See Rev. Rul. 195, 1954-1 Cum. BuLl. 47; Hayes, Deductions for Travel and Entcrtainment Expense, 4 ARTHUR Young J. 1 (1957) ; Perkins, Recommendations for Prevchting Disallozvance of Expenses for Travel and Entertainment, $4 \mathrm{~J}$. TAXATION 10 (1956). 
the deduction and its amount. Credible oral evidence of expenses will be accepted and, if the amounts appear reasonable, the deduction will be considered established..$^{80}$

Besides offering testimony of particular expenditures, morever, the executive may be able to establish a deduction based on his average travel costs over a period of time or the average cost of entertaining in an ordinary manner. ${ }^{81}$ Testimony as to business travel costs generally, however, will not be accepted by the Tax Court, even in statistical form. ${ }^{82}$ Nor will the Tax Court view as adequate evidence checks drawn by the executive of a close corporation against the corporate treasury in round amounts, with a cryptic notation on the stubs such as "travel expenses." ${ }^{83}$ Here, the executive can at least seek to establish total expenditures by returning the amount drawn from the corporation but not spent, or by obtaining reimbursement for expenditures in excess of the amount advanced by the corporation. ${ }^{84}$

When travel or entertainment involves use of facilities owned by the executive or maintained by him for general use, records should indicate not only the total expenditure but also the facts which support apportionment between business and personal use. ${ }^{85}$ Under the rule of Cohan $v$. Commissioner, ${ }^{86}$ a deduction for business expenses which have unquestionably been incurred will not be entirely lost for failure to prove their exact amount. But the deduction may be lost to a large extent since the taxing authorities tend to allow less to the taxpayer than the amount claimed by him..$^{87}$

\section{Other Forms of the Expense Account: "Perquisites" of Office}

Discussion of the expense account has thus far been concerned primarily with expenses paid or reimbursed in cash. A less tangible but often equally import-

80. Rev. Rul. 195, 1954-1 Cum. Bulr. 47.

81. John A. Lovelady, 15 CCH Tax Ct. Mem. 1498 (1956) ; Charles O. Gunther, Jr., $13 \mathrm{CCH}$ Tax Ct. Mem. 984 (1954) (daily total travel cost).

82. Charles O. Gunther, Jr., supra note 81 , at 990 (estimate of $\$ 16.50$ per day based on article in Baltimore Sun about average daily travel cost of executives held no substitute for cost records or estimate of taxpayer's actual expenses).

83. E.g., B. F. Crabbe, 15 CCH Tax Ct. Mem. 216, 220-21 (1956).

84. See Siegfried v. United States, 55-2 U.S.T.C. I 9531 (N.D. Okla. 1955) (reimbursement received by insurance executive reporting travel cost to corporate employer on monthly vouchers specifying categories of transportation, hotel, food and miscellaneous held not to constitute income). See also Perkins, supra note 79, at 11-13.

85. See Richard A. Sutter, 21. T.C. 170 (1953); cf. Thomas W. Briggs, $15 \mathrm{CCH}$ Tax Ct. Mem. 440, 447-48 (1956).

86. 39 F.2d 540 (2d Cir. 1930).

87. For a table illustrating application of the Cohan rule by the Commissioner and the Tax Court in twenty-nine decisions, see Institute for Bustness Planning, AcCoUnting for Travei and Entertainment Expenses $§ 2$ (1958). For decisions affirming the Commissioner's allocation of expenses, see Wm. T. Stover Co., 27 T.C. 434, 436-37, 440-41 (1956) (upholding Commissioner's 50\% disallowance of cabin cruiser expenses); 
ant form of expense account is the benefit received in kind-for example, the use of a company car and chauffeur, or an airplane, ${ }^{88}$ or an apartment or estate owned or maintained by the company. ${ }^{89}$ The company will often operate a dining room for executives where meals are served without charge or at cost. ${ }^{90}$

Richard A. Sutter, 21 T.C. 170 (1953) (affirming Commissioner's 75\% disallowance of claimed operational expenditures for boat); Charles S. Guggenheimer, 18 T.C. 81, 85-86 (1952) (20\% of claimed deduction for travel and entertainment expenses allowed by Commissioner and affirmed by Tax Court); see also B. F. Crabbe, $15 \mathrm{CCH}$ Tax Ct. Mem. 216, 219-21 (1956) ; Anne Klein Ansley, 12 CCH Tax Ct. Mem. 1110, 1114, 1116 (1953). For decisions taking an intermediate position between the minimum allowed by the Commissioner and taxpayer's claimed deduction, see Frank L. Kluckhohn, 18 T.C. 892 (1952) (Commissioner's allowance of one half of general travel expenses in connection with lectures and disallowance of entire cost of trip to Australia; modified by Tax Court under the Cohan rule to allow as deductions two thirds of general travel costs and $70 \%$ of expense of Australian trip); see also Albert L. Sanderson, $16 \mathrm{CCH}$ Tax Ct. Mem. 105 (1957); Louis Reinheimer, $16 \mathrm{CCH}$ Tax Ct. Mem. 56, 60 (1957); William and Jeanne Auerbacher, 15 CCH Tax Ct. Mem. 1147, 1151 (1956) (Tax Court allowed in lieu of $\$ 2,303.36$ claimed, nominal $\$ 100$ deduction for unspecified business entertaining at club); Arthur Brookfield, $15 \mathrm{CCH}$ Tax Ct. Mem. 247, 254 (1956) (Cohan rule applied to deduction claimed for cost of technical magazines); Norman M. Hussey, $11 \mathrm{CCH}$ Tax Ct. Mem. 141 (1953) (Tax Court allowing $\$ 600$ of $\$ 895$ claimed by taxpayer as deduction for club expenses).

88. In 1953, company-owned airplanes outnumbered those of scheduled airlines seven to one. N.Y. Times, July 19, 1953, § 3, p. 1, cols. 6-7, p. 5, col. 1. See id., Aug. 1, 1954, $\S 1$, p. 87 , col. 7 (business planes numbered 21,500 , almost seventeen times those operated by domestic airlines); Burgess \& Neunoff, Managing Company Airplanes 3 (Nat'1 Ind. Conf. Bd. Studies in Bus. Policy No. 65, 1954). See also N.Y. Times, July 6, 1952, p. 5, col. 2 (describing plane fleet of Parker Pen Co.).

89. See Chandler v. Commissioner, 119 F.2d 623, 626-28 (3d Cir. 1941) (executive occupying with his family a rent free lodge owned by corporation of which he was the sole stockholder held to have received compensation in an amount equal to the lodge's rental value). But see Richards v. Commissioner, 111 F.2d 376 (5th Cir. 1940) (rental value of corporate premises occupied by chief executive and his wife-together the sole shareholders-held to constitute a gift from the corporation to the husband, the court emphasizing that under Louisiana law families often place title to property in a corporation to facilitate transfer to children after parents death). See discussion of the employer convenience rule note 90 infra.

90. For a discussion of such arrangements, see Wilson John Fisher, 23 T.C. 219 (1954) ; Canary, Fringe Benefits to Employees, in Encyclopedia of Tax Procedures 465, 466-67 (1956) ; cf. Everett Doak, 24 T.C. 569 (1955), rev'd, 234 F.2d 704 (4th Cir. 1956) (involving a self-employed person rather than an employee). "'The Hanover [Bank] provides [free] meals for its employees because of the crowded conditions in public restaurants and the unsatisfactory consequences to both the bank and its staff, and in the interests of health.' "N.Y. Times, July 8, 1957, p. 35, cols. 2-3.

If meals and lodging are furnished solely for the convenience of the employer, their value is not taxable to the employee. INT. Rev. CODE of 1954, § 119. See Note, 42 CorNELL L.Q. 433 (1957) ; Comment, 53 MicH. L. Rev. 871 (1955). However, if the cost of meals and lodging is taken into account in setting the pay of employees, or if employees not furnished meals or lodging receive higher salaries, the value of meals and lodging is taxed as compensation. Herman J. Romer, 28 T.C. 1228, 1240-42 (1957) ; Int. Rev. Special Rul- 
The corporation may also offer recreational facilities, ${ }^{91}$ grant free medical examinations, ${ }^{92}$, provide the use of lunch and country clubs, sell its own products at a discount ${ }^{93}$ or pay expenses at resort hotels used for rest or recuperation..$^{94}$ A benefit of this nature is generally thought of as a "perquisite" accruing to an executive by virtue of his office or position-by definition, "a gain or profit incidentally made from employment in addition to regular salary." A cash expense

ing, in 5 CCH 1951 STAND. FED. TAX REP. $\|$ 6191. Sometimes, the value of meals and lodging may be considered part taxable compensation and part tax free. Hazel W. Carmichael, 7 CCH Tax Ct. Mem. 278 (1948); Olin O. Ellis, 6 T.C. 138 (1946). In determining whether meals and lodging are compensation, the provisions of the executive's employment contract are not conclusive. INT. REv. CODE OF 1954, § 119.

91. See N.Y. Times, Oct. 2, 1955, \& 3, p. 1, col. 8, p. 9, col. 2 (describing Union Carbide's many company-sponsored activities). In 1955, company and employee outlays for company-sponsored recreational programs amounted to one billion dollars. Id., April 17, 1955, \$ 3, p. 4, col. 3; see id., Nov. 12, 1956, p. 47, col. 3, p. 48, col. 2 ("Today there is hardly a large concern that doesn't have [an industrial recreation program] ..."). See also Slaymaker Lock Co., 18 T.C. 1001 (1952) (allowing deduction for cost of improving land and buildings donated by the company to foremen's association, to be maintained by the association as recreational facility for all employees of the company).

92. Many companies now offer their executives periodic health examinations. Bosses' Health, Bus. Week, Oct. 17, 1953, p. 135. Socony-Vacuum Company, for instance, provides for semi-annual examination for all top executives over sixty, with more widely-spaced examinations for younger executives. Ibid. See Southern NATURAL Gas Co., 1956 ANNUAL REPORT 24. Lukens Steel Corporation requires a medical examination as an incident of promotion to a top position. Fortune, Aug. 1957, p. 92. See also Wall Street Journal, April 2, 1956, p. 1, col. 6 (describing spread of executive health plans) ; Symposium, Safcguarding Executive Health, 46 MGMT. REv. 58 (May 1957).

An important problem raised by these medical examination plans is disclosure of results to the employing corporation. In the normal doctor-patient relationship, such disclosure would appear in violation of professional ethics. However, until recently at least, executives seem to have been willing to have their physical condition disclosed to their superiors. Bosses' Health, supra.

93. "In practice, cash discounts to employees, even though they are sufficiently large to form a part of the wage pattern, are not reported as taxable income. However, in theory they probable are taxable and there are, of course, many other fringe benefits that would meet the same standards." Employee and Executive Compensation Arrangements, in Tax Planning in Business Policy 28-29 (Proceedings of the Am. Inst. of Accountants 1955 Tax Conf. for Executives, 1956).

94. Large-scale advertising by health resorts and hotels, emphasizing the alleged tax benefits of their use by executives at company expense, prompted the Internal Revenue Service to issue a ruling explaining that no business or medical expense deductions for such expenditures were allowable, either to the company or the executive. Rev. Rul. 130, 1957-1 CUM. BuLI. 108. Conventions are often held at resort hotels and sometimes on cruises. See N.Y. Times, Oct. 18, 1953, \& 3, p. 1, col. 6; see also id., Oct. 23, 1953, p. 36, cols. 2-3, p. 38, cols. 4-5; id., Oct. 20, 1953, p. 41, cols. 6-7, p. 44, col. 3 (annual convention of Savings Bank Association of New York held on cruise to Havana). In 1957, Commissioner Harrington directed agents to give attention to "the use of alleged branch offices established in resort cities for the sole purpose of sending business executives to such cities for vacations." What's Happening in Washington, Prentice-Hall Accountant's Weekly' Rep., July 8, 1957, § 2, p. 2. 
allowance may similarly be viewed in some businesses and incident to some positions as less of a business necessity than a perquisite. ${ }^{95}$

The same corporate and tax principles discussed in connection with payment or reimbursement in cash appear applicable to this type of benefit. Thus, to the extent that the executive's use of facilities made available by the company is solely for business purposes or for the company's convenience, the benefit to the executive is analagous to the benefit received from direct corporate payment of properly incurred business expenses. This established, it is reasonable to conclude that the executive realizes no taxable income. On the other hand, if his use of such facilities is found to be for personal rather than business purposes or for both purposes equally, the value of such use constitutes taxable compensation. ${ }^{96}$ Even so, if the use for personal purposes is occasional or incidental only, it may be deemed de minimis. ${ }^{97}$ Moreover, it may be argued that a specific perquisite, such as a recreational facility, is in the nature of a gift. ${ }^{98}$

For the company, expenses of this nature are generally deductible either as ordinary and necessary business expenses or as compensation, subject in the latter case to the limitation of reasonableness.

In recent years, corporations have sent executives to management training courses, of which those at the Harvard School of Business are perhaps the best known. Corporate funds expended for such a purpose would clearly be a proper business expense of the corporation. Similarly, any reimbursement'of expenses made to the executive would not be taxable income to him. With regard to expenses incurred by the executive for which he is not reimbursed, a business deduction by him should be recognized on the principle that he was required to attend the course in order to retain the position which he occupied.99

Other forms of perquisite involve provisions-sometimes incorporated in

95. "In the process of liberalizing expense handling, several companies tell us that they have reached the point where they catalog expense accounts with other fringe benefits." Executive Expense Practices, Am. Bus., Jan. 1957, p. 30.

96. Mintz, Executive Expense Accounts and Fringe Benefits: A Problem in Management, Morality, and Revenue, $1 \mathrm{~J}$. TaXation 2 (1954).

97. See Rodgers Dairy Co., 14 T.C. 66, 73 (1950) (executive's personal use of corporate automobile held "so small that [it] ... may be disregarded" in determining corporation's right to deduct car maintenance and operating expenses) ; cf. Penn v. Robertson, 29 F. Supp. 386 (M.D.N.C. 1939) ; I.T. 3015, XV-2 Cum. Bull. 136 (1936). See also McDonald, Travel and Entertainment Expenses, in ENCXCLOPEDIA of TAx Prockdures 451, 457 n.9 (1956) ("The courts tend not to concern themselves with 'nice' questions of theory in connection with expenditures which are patently moderate").

98. See Slaymaker Lock Co., 18 T.C. 1001 (1952).

99. See Note, 66 Harv. L. Rev. 1508, 1510 (1953); cf. Coughlin v. Commissioner, 203 F.2d 307 (2d Cir. 1953) (allowing expenses of attorney attending tax institute). For employer reimbursement practices, see Practices of 100 Companies Compensating Management Employees for Certain Expense Considered Benteficial to Company Work, 39 MGMT. REv. 459 (1950). Only $44 \%$ of the companies included in this survey then compensated their executives for all expenses incurred by them in attending training courses. 
the employment contract ${ }^{100}$ - for vacations, ${ }^{101}$ absence because of illness and the like. These are often less susceptible to adequate corporate and tax control than expense accounts paid in cash.

\section{The Position of the Treasury Department}

The Treasury Department has been keenly aware of the problems posed by expense accounts. In the past, considering the solution to rest primarily in enforcement, it has periodically announced vigorous enforcement campaigns. ${ }^{102}$ The great expense of a campaign sufficiently comprehensive in itself to be both thorough and dissuasive for the future has proved prohibitive. Accordingly, the Treasury Department has from time to time considered other measures. The most recent of these derives from a nominal provision of many years standing requiring that an employee report on his own tax return the receipt of amounts reimbursed for travel. ${ }^{103}$ This requirement was little known and rarely observed.

In 1957, the Treasury Department proposed expansion of the regulations to include reporting of all payments received by an employee as reimbursement of expenses. In conjunction with the new regulation, the Department published an income tax form which would have required total reimbursed expenses to be reported in the employee's gross income and claimed business expenses to be

100. See Washington \& Rothschild app. $\mathrm{K}$, If 4,5 ; see also CASEy \& Rothschild exh. 171 (Lerner Stores contract with Benjamin J. Timoner granting the right to receive "reasonable vacations and subject to absences on account of temporary illnesses"); id. exh. 172 (Universal Pictures Co. contract with Edward Muhl affording executive "leave of absence for a consecutive period of four (4) weeks" with continuing compensation, but denying him the privilege of taking other employment during vacation period without employer's consent). As to provisions for continued salary payments during illness or disability, see id. exh. 176 (Noma Elec. Corp. contract with Henri Sadacca, providing for continuance of salary during sickness or partial disability); id. exh. 186 (Deep Rock Oil Corp. contract with W. H. Garbade providing for $\$ 15,000$ per annum for ten years payable to executive if disabled while employed).

101. Cf. McCoy-Brandt Mach. Co., 8 B.T.A. 909 (1927) (allowing payment of vacation expenses to skilled labor in short supply as an ordinary and necessary expense deduction). For the view that the payment of such expenses would not have been held taxable to the employees in that case, see Canary, supra note 90, at 473.

102. See N.Y. Herald Tribune, May 25, 1952, \$2, p. 10, col. 1 ("income tax authorities have announced a crackdown on entertainment expense deductions"); N.Y. Times, Nov. 10,1953 , p. 54, col. 3 (Commissioner Andrews "says agents will check carefully deductions made for entertainment") ; $i d$., April 25, 1952, p. 32, col. 4 ("Tax agents have been ordered to impose full income levies on any expense allowances that appear to be hidden salaries"); see also U.S. News and World Report, July 9, 1954, p. 96 (interview with Commissioner Andrews). For announcements of prior campaigns, see Mintz, supra note 96, at 2; Osmond, The Corporate Executive and the Business Expense Deduction, 33 TAxes 68 (1955).

103. U.S. Treas. Reg. $111, \S 29.23$ (a)-2 (1943), as amended, T.D. 5458, 1945 Cun. BuLL. 45. 
deducted with appropriate itemization. ${ }^{104}$ Strong protests from many quarters $^{105}$ led to abandonment of this requirement and to a proposed Treasury regulation which, in substance, would require detail only in cases in which a flat expense allowance is paid and no accounting of expenses is submitted to the employer. ${ }^{106}$ The regulation would add little of substance to present requirements and, in fact, may repeal the long-standing nominal requirement of reporting amounts reimbursed for travel. ${ }^{107}$ Currently, the Treasury Department proposes to inaugurate new measures to improve enforcement and has indicated that it will welcome suggestions for a constructive program. The problem, as stated by Dr. Dan Throop Smith, Deputy to the Secretary of the Treasury, has been one of preventing the abuse of expense accounts on the one hand and avoiding unnecessary harassment on the other. ${ }^{108}$

\section{A Suggested Program}

That the expense account has been abused in all fields, not excluding the academic profession, no longer seems open to question, though disagreement exists over the extent of the abuse. ${ }^{109}$ Among the various remedies that have been suggested, the following are typical:

1. Abuse of the expense account has been described as chiefly the by-product of high taxes which tend to make criminals of everyone. If tax levels were reduced to reasonable levels, the argument runs, the abuse would largely dis-

104. 1957 U.S. Tax Form 1040, line 6(a) ; General Instructions, Publication 3, at 6 (1957); see Int. Rev. News Release IR-204, in 5 CCH 1957 StAnd. Fed. TAX REP. If 6932: "The new line will enable the Service to give attention to those returns where deductions for expenses appear to be disproportionate in relation to the employee's income and occupation, and thus aid in detection of abuses that have arisen in this area." After the form was distributed, the Internal Revenue Service announced that it would not be applied "retroactively" to 1957. 1957 INT. REv. BuLl. No. 48, at 83; see U.S. News and World Report, Dec. 6, 1957, p. 97.

105. See id., Nov. 22,1957, p. 33 (referring to the "nation-wide furor" stirred up by the new income tax forms). "You have no idea of the pressure that was brought on the Service from people who get expense-account money." Id., Dec. 6, 1957, p. 97 (quoting an official of the Internal Revenue Service); see also Wall Street Journal, Feb. 14, 1958, p. 1, col. 1, p. 11, col. 1. The requirement that expenses be included in gross income was also attacked as unconstitutional. See, e.g., 15 THE TAX BARoMeter No. 475 (1958).

106. Proposed U.S. Treas. Reg. 103, § 19.1, 23 FEd. Reg. 1698 (1958).

107. Cf. U.S. News and World Report, March 7, 1958, p. 86: "The new policy is likely to prove easier on taxpayers than the one that was in force before the furor arose over line 6(a)."

108. Seminar of the Tax Institute, The Effect of Tax Policy on Executive and Worker Compensation (Princeton, N.J., May 19, 1958) ; compare Address by UnderSecretary of the Treasury Scribner, Tax Executives' Inst. Meeting, Feb. 17, 1958.

109. Compare Sainders, Effects of Taxation on Executives 152 (1951) ("That there are abuses is certainly true, though very little that looked like abuse has appeared in this inquiry"), with Smith, Watch Your Expense Accounts, Harv. Bus. Rev., Jan.-Feb. 1958, pp. 120-21. See Note, 38 VA. L. REv. 771 (1952). 
appear. ${ }^{110}$ With respect to this point, it should perhaps be observed that abuse of expense accounts is not solely the result of taxes-witness the expense account's historic name of "swindle sheet."

2. At the opposite extreme are suggestions that the Code be amended to eliminate entertainment as a tax deduction. ${ }^{111}$ Assuming that it is possible to distinguish entertainment expense from related costs incidental to travel, the denial of a tax deduction for entertainment would appear to be inconsistent with the concept of an income tax based on net income after expenses. ${ }^{112}$

3. A middle course is now being followed by the Treasury, consequent to its abandonment of the new reporting requirement. In the case of the large publicly-held company, the Treasury proposes to rely heavily on the accounting and accountability of the employee to his employer, with occasional governmental spot checks. In the context of closely-held smaller companies, present Treasury practice calls for continued emphasis on enforcement.

There is no doubt that the problem of controlling the stockholder-executive of the closely-held company whose affairs are identical with those of the company which he manages must necessarily be met by enforcement. ${ }^{113}$ A very different problem is posed for other companies. The large, publicly-held company, subject to supervision by a variety of government agencies and sensitive to its position in the eye of public interest and attention, audits expense accounts of its executives with greater care than the smaller company. ${ }^{114}$ Insurance companies and public utilities are under the active supervision of regulatory or ratemaking agencies, and audit their employees expense accounts with still greater care. And banks that are strictly controlled and independently audited review expense accounts with the greatest care of all.

If all corporations could be made as sensitive to the need for thorough internal audits as are national banks and some publicly-held companies, the problem of expense accounts would be reduced to manageable proportions. How can

110. See Livingston, Wives Can Be Deductible, Washington Post, May 2, 1956, p. 27, cols. 3-4 ("The best relief from tax amorality is lower taxes. That would take the incentive out of fudging accounts ..."); cf. Wormser, The Third American Revolution: A Reform Movement Gone Wrong, 39 A.B.A.J. 389, 438 (1953) ("The unrealistic attempts to equalize us by taxation have made criminals of countless Americans").

111. See Smith, supra note 109 , at 122 , not favoring this course but stating: "We have no right to a tax on net income. The government could, if it wished, revise corporate and individual income taxes to make them apply on gross income." By recommendations of the King Committee, see H.R. REp. No. 2518, 82d Cong., 2d Sess. 29-31 (1952), legislation was proposed to prohibit deductions of expenses not substantiated by accurate records, see H.R. 7893, 82d Cong., 2d Sess. (1.952).

112. Cf. McDonald, supra note 97, at 463-64 ("Strict record requirements as an essential to such [travel and entertainment] deductions might be the very path to satisfactory justification of all that the Treasury Department is now seeking to limit").

113. See note 9 supra and accompanying text.

114. See SANDERS, op. cit. supra note 109, at 154 (concluding that "the big public companies are more rigorously policed, and their accounts are subject to more internal and external scrutiny ..."). 
corporations best be made responsive to this need? How can inadequate auditing of expense accounts or overlooking careless and irresponsible use of the expense account privilege be made disadvantageous to the employer corporation? How can the corporation's directors, who are ultimately responsible for expense account audits, be given an incentive to ensure that the expense accounts of all employees are reviewed with care? A relatively simple answer to these questions may lie in disallowance of a corporate tax deduction for expenses deemed personal to a corporate employee.

At the present time, expenses improperly paid or reimbursed to the executive of a publicly-held company, or to a nonstockholder executive of a closelyheld company, may be disallowed on audit of his personal tax return and taxed to him as additional compensation. With rare exceptions, however, wrongly paid or reimbursed expenses cannot properly be disallowed as employer tax deductions since, if not deductible as expenses, they constitute deductible compensation. $^{115}$ The disallowed expenses are usually found on audit of a corporation's return; but, except in the case of closely-held companies, correlation between audits of the corporation's return and the returns of its executives has been difficult-at least up to now.

If the field agent auditing the return of the corporation were authorized to disallow as a corporate deduction payments to employees for personal expenses, these payments would become more than twice as expensive to the corporation. The possibility of such a disallowance might itself operate as a stimulus to more effective controls within the corporation., ${ }^{116}$

Further, employers should be required to file information returns pertaining to certain expenses of employees. For example, an employer should have to disclose expenses paid or reimbursed in the aggregate over a designated amount and, irrespective of value or amount, also report specific facilities, such as ranches, apartments or airplanes, made available only to a single executive or

115. Company payment or reimbursement of an executive's personal expenses (for example, of rent for an apartment used by the executive apart from his work) would appear tantamount to additional compensation taxable to the executive and deductible by the company. See notes 36-38 supra and accompanying text. As a practical matter, in the case of publicly held companies, some field agents have disallowed the corporate deduction of personal items without seeking to tax the executive upon the company's payments. Their analysis appears to end with the statement that the payments were not normal or necessary expenses of the corporate business.

In the case of the closely-held company, improper payments by the company for the benefit of a stockholder-executive may be held dividends and hence nondeductible by the company. See cases cited note 38 supra. Moreover, when an executive is unable to prove the expense item, a close corporation with no independent records will often find it difficult to substantiate the contention that the payment is deductible as compensation. See P. S. Thorsen \& Co., 15 B.T.A. 1281 (1929) ; Frishkorn Real Estate Co., 15 B.T.A. 463, 466 (1929). See also Donald V. Smith, 6 CCH Tax Ct. Mem. 548, 561. (1947) (fixed expense allowance found not "reasonably equivalent" to unitemized but estimated expenses).

116. As one commentator put it, "a conscience works best when somebody peeks over your shoulder." Livingston, supra note 110. 
group of executives. A suggestion made by J. S. Seidman is that corporations be required to state, in a separate line of the corporate return, aggregate expenditures for travel, entertainment and promotion, with a separate schedule for all payments to insiders.

Proposals such as these will not be popular. They raise problems of their own and call for refinement to avoid practical problems and undue bookkeeping expenses. Nonetheless, thinking should be directed toward requiring information from and imposing penalties on the agency that improperly pays, rather than concentrating solely on the individuals that receive.

\section{SUMMARY}

Methods of paying or reimbursing expenses incurred by executives vary from company to company but may be divided into three general categories.

The first embraces payment of a flat allowance from which the executive is expected to pay expenses incurred by him as an employee of the corporation. For tax purposes, such an allowance has been treated much the same as salary, except that the corporation does not have to withhold income taxes or make social security payments on it. ${ }^{117}$ The company must nevertheless report the allowance on its information return, 118 and the executive must include in his income tax return the amount of the allowance, even though he may then deduct his expenses. ${ }^{119}$ The allowance assures the executive a fixed amount from the company, and its evidentiary value as a corporate declaration that expenditures made by the executive constitute business necessities of the corporation helps him to establish tax deductions for his expenses. To the extent that the executive's expenses exceed his allowance and are not reimbursed by his corporation, however, he may encounter difficulty in having the excess deductions allowed on his own return.

The second category consists of reimbursement upon appropriate accounting by the executive, either up to a fixed amount provided for by contract or of designated expenses as incurred. Provision for such expenses may be made in the employment contract or may be a matter of company practice or oral

117. The definition of wages from which income tax is to be withheld excludes reimbursement or advances for travel and other necessary and ordinary expenses when paid separately, when their amount is stated separately, or when paid together with wages subject to withholding. U.S. Treas. Reg. $120, \S 406.207$ (c) (1953). The value of meals and lodging is subject to withholding if in the nature of compensation. U.S. Treas. Reg. 120, $\S 406.207$ (a) (5) (1953). Wages subject to the Federal Insurance Contributions Act, incorporated into INT. REv. CODE oF 1954, $\$ 3101-25$, are defined in the same manner as wages subject to withholding, U.S. Treas. Reg. $\$ 31.3121$ (a) -1 (1956). See U.S. Treas. Reg. $\$ 31.3121$ (a) -1(h) (1956) which is identical with U.S. Treas. Reg. 120, $\$ 406.207$ (c) (1.953), in regard to amounts paid as reimbursement or as advances for travel and other expenses. See also note 43 supra.

118. U.S. Treas. Reg. $118, \S 39.147-2$ (1953) ; see U.S. Treas. Reg. 111, $\$ 29.147-2$ (1943), as amended, T.D. 5313, 1944 Cuar. Bull. 308, 309, T.D. 5480, 1945 Cun. Buls. 234, T.D. 5687, 1949-1 Cum. BuLr. 9, 33 (forms 1096, 1099).

119. See Proposed U.S. Treas. Reg. 103, § 19.1-3, 23 FED. REG. 1698 (1958). 
understanding. The expenses may be paid directly by the corporation or reimbursed by the corporation to the executive. As distinguished from the flat expense allowance, expenses so reimbursed need not be reported by the executive on his tax return. ${ }^{120}$

The third category is payment of expenses out of the executive's agreed compensation. A clause contemplating this handling of expenses, either in the employment contract, by memorandum or by policy statement, may be desirable for an executive incurring expenses which he expects to claim as a deduction on his own return. ${ }^{121}$

In England, high taxes have led to the increasing use of perquisites as a form of tax evasion. ${ }^{122}$ This practice is considered to be a cause of deterioration in public moral standards. A similar deterioration, affecting both public and private life, is said to have flowed from abuse of the expense account in the United States. ${ }^{123}$

Efficient management generally recognizes that lax use of expense accounts and free spending of the expense dollar result in careless handling and unrestrained consumption of company money generally. But no effective control of expense accounts has yet been devised. In the final analysis, what the executive believes to be the attitude of his company toward large expenses is the major factor and deterrent. ${ }^{124}$ Although some corporations-principally large publicly-held ones-are subject to stringent policing of expenses, others are relatively free from external control.

A solution to the expense account problem may lie in stimulating all employers to audit their employees' expense accounts more carefully. Suggested for consideration is the disallowance of corporate deductions paralleling business expenses claimed by employees but found to be personal, together with a requirement that the corporation file information returns for expenses of certain types and in excess of a designated aggregate amount.

\section{CONCLUSION}

The loose use of expense money, with continued treatment of the expense account as the proverbial swindle sheet, can no longer be condoned as a peccadillo. The Treasury Department is keenly aware of the problem, but its efforts at regulation have met with stubborn resistance both from the luxury services sustained by the expense account and from individuals who find the account essential to their accustomed scale of living.

120. See ibid.; text at note 106 supra.

121. See note 53 supra and accompanying text.

122. See Gorer, Pinch on Britain's Upper Middle Class, N.Y. Times Magazine, Aug. 26, 1956, p. 13, col. 1; Jessup, Britain's Road Back, Fortune, May 1950, pp. 80, 85.

123. See, generally, authorities cited notes 1-6 supra.

124. "Spending habits of the men at the top set an example for the entire organization ...." Exccutive Expense Practices, supra note 95, at 32; cf. Livingston, Adams' Plight: Symbol of Ontr Amoral Times, Washington Post, June 20, 1958, p. B9, col. 4. 
Pointing out that there is no simple answer to any complex issue, Secretary of the Treasury Anderson recently declared that solution of such issues today requires "new thinking, hard and inquiring; new questioning, not about the variations of an existing pattern, but about the possibilities of starting new ...."125 The expense account presents a complex issue. Its abuse is leading to the disintegration of our self-assessment system of taxation and is undermining confidence in the integrity not only of our tax administration but of the government as a whole. ${ }^{126}$ The palliatives of enforcement will no longer serve. What is needed is an imaginative and comprehensive program derived from the new, hard and inquiring thinking called for by Secretary Anderson.

\section{8.}

125. Commencement Address of Hon. Robert B. Anderson, Williams College, June 8 ,

126. "A society depends on the standards which men in power, men in high places, men in the professions impose on themselves. When Government officials, professional men, and corporation officials engage in self-serving practices and use the expense account to raise their standards of living at taxpayer expense, they bring down on themselves not only censure but, ultimately, the structure which has put them where they are-on top. If they shrink from paying taxes, if they condone misapplication of the expense account, why shouldn't everyone?" Livingston, supra note 124. 


\section{THE YALE LAW JOURNAL}

STEPHEN N. ShulMan
Editor-in-Chief

ROBERT T. BASSECHES

Alan J. Hruska

Comment Editors

\section{ROBERT L. BARD}

Thomias D. Barr

FREDERICK L. BernsteIN

David P. Bicks

Noraran A. Birales

BenjaAmin W. Boley

Richard A. Brady

Newton D. BrenNer

David Burres

Peter D. Caldwell

Inutra M. Chapman

SyDNEY M. Cone, III

Paul H. DeCoster

ROBERT J. Dez Tufo

ROBERT J. ENGELAIAN

ERNEST J. ETTLINGER

Mitchel J. Ezer

Arthur Fleischer, $\mathrm{J}_{\mathrm{r}}$.

\author{
Milton P. DeVane \\ Article and Book \\ Review Editor
}

Wirliam C. Baskin, JR. Managing Editor

SETH E. Frank

ThoMAs N. FroHoCK

DAvid GoldBERG

BURT W. GrIfFin

Milton S. Gwirtzaran

NEIL S. HECHT

REUBEN L. HedLund

JACOB W. HELLER

JEROLD H. ISRAEL

STEPHEN J. JEIIN

WILLIAM A. Kass

N. Herschel Koblenz

J. D. LAMBERT

IRVING I. LESNICK

JoHN C. McGuIre

FrEDERICK W. MCNABB, JR.

JoHN K. MCNULTY
Guido Calabresi

W. L. F. FELSTINER

Note Editors

\author{
RICHARD MARLIN \\ RICHARD M. MEYER \\ JERROLD L. MORGULAS \\ Hugh G. Moulton \\ Michael J. Nassau \\ WALTER W. ObERREIT \\ Richard W. Pendleton, JR. \\ Charles J. Prentiss \\ BURTON RAFFEL \\ RICHARD SEXTON \\ BARRY SIDMAN \\ Douglas O. SMith, JR. \\ LEWIS A. STERN \\ CoLIN C. TAIT \\ STANLEY E. ToBin \\ Patricta W. Weinberg \\ T. Cectl Wray, JR. \\ Alan L. WuRTzer
}

\footnotetext{
MARIE MCMAHON

Business Secretary
}

\section{CONTRIBUTORS TO THIS ISSUE}

Harry H. Wellington. Associate Professor, Yale Law School.

V. Henry Rothschild. Member of the New York and Federal Bars.

Rudolf Sobernetm. Member of the New York and District of Columbia Bars. 